Review Article

\title{
Mechanistic Rationale and Clinical Efficacy of Hyperbaric Oxygen Therapy in Chronic Neuropathic Pain: An Evidence-Based Narrative Review
}

\author{
Simone Schiavo ${ }^{\mathbb{D}},{ }^{1}$ Julian DeBacker, ${ }^{1}$ Carine Djaiani, ${ }^{1}$ Anuj Bhatia, ${ }^{2}$ Marina Englesakis, ${ }^{3}$ \\ and Rita Katznelson (iD) \\ ${ }^{1}$ Hyperbaric Medicine Unit, Department of Anesthesiology and Pain Medicine, Toronto General Hospital, \\ University Health Network, University of Toronto, Toronto, Ontario, Canada \\ ${ }^{2}$ Department of Anesthesiology and Pain Medicine, Toronto Western Hospital, University Health Network, University of Toronto, \\ Toronto, Ontario, Canada \\ ${ }^{3}$ Library and Information Services, Toronto General Hospital, University Health Network, Toronto, Ontario, Canada \\ Correspondence should be addressed to Rita Katznelson; rita.katznelson@uhn.ca
}

Received 18 September 2020; Revised 11 March 2021; Accepted 10 April 2021; Published 22 April 2021

Academic Editor: Federica Galli

Copyright (c) 2021 Simone Schiavo et al. This is an open access article distributed under the Creative Commons Attribution License, which permits unrestricted use, distribution, and reproduction in any medium, provided the original work is properly cited.

\begin{abstract}
Background. Chronic neuropathic pain is a condition affecting an increasing proportion of the general population and its management requires a comprehensive, multidisciplinary program. A growing body of evidence supports the use of hyperbaric oxygen therapy (HBOT) in several chronic neuropathic pain conditions; however, its role and efficacy remain unclear. Purpose. To summarize current evidence for the mechanistic rationale of HBOT in chronic neuropathic pain conditions and to evaluate its clinical efficacy. Methods. This narrative review was conducted after searching the following databases (Medline, Embase, Cochrane, PsycINFO, the Web of Science, Scopus, ClinicalTrials. gov, WHO ICTRP, and ProQuest Digital Dissertation) from January 1946 to March 2020. Articles published in English that involved either animal or human studies with acute or chronic neuropathic pain evaluating any HBOT-related intervention were included. Results. A total of 2971 citations were identified. A total of 29 studies were included in this review. The mechanisms of action for HBOT use in neuropathic conditions included the primary effects of hyperoxia and edema resolution, as well as the secondary effects pertinent to the production of oxygen and nitrogen reactive species (serving as pain signaling molecules), nitric oxide-dependent release of opioid peptides, and reduction of inflammatory mediators. A robust evidence for HBOT use in the clinical setting was associated with chronic regional pain syndrome and chronic primary bladder pain syndrome. Some evidence supported its use for chronic secondary (peripheral) neuropathic pain including radiation-induced plexus neuropathies, postherpetic neuralgia, and trigeminal neuralgia. Conclusions. HBOT has been shown to have antinociceptive and analgesic effects in animal models of inflammatory, neuropathic, and chronic pain. Human studies demonstrated beneficial effects of HBOT in improving clinical outcomes such as pain scores, pain-related symptoms, and quality of life. A systematic methodology of HBOT application is necessary to confirm its safety and efficacy.
\end{abstract}

\section{Introduction}

Chronic neuropathic pain is a silent, global health epidemic requiring a novel approach to improve the treatment methodologies. It is estimated that $10-30 \%$ of adults live with a chronic pain condition and more than half of these patients report continuous moderate to severe pain and reduced quality of life resulting in job loss or reduced efficacy at workplace $[1,2]$.

Neuropathic pain, as defined by the International Association for the Study of Pain (IASP) Neuropathic Pain Special Interest Group, is "pain arising as a direct consequence of a lesion or disease affecting the somatosensory system" [3]. Controversy in understanding chronic pain as a 
symptom or a disease has led to a new classification for chronic pain disorders [4], reclassifying some neuropathic pain conditions as chronic primary pain disorders [5] (Table 1) and others as chronic secondary (central or peripheral) neuropathic pain disorders [3] (Table 2). Primary chronic pain disorders differ from the secondary ones in that they are independent of identified biological or psychological conditions.

Currently, the first-line management strategy for chronic neuropathic pain is based on multifaceted approach including tricyclic antidepressants, serotonin norepinephrine reuptake inhibitors, and gabapentinoids, as well as topical and transdermal substances. The second-line therapy consists of a combination of first-line medications with tramadol or tapentadol. Serotonin-specific reuptake inhibitors/ anticonvulsants/N-methyl-D-aspartate receptor antagonists and interventional therapies are suggested as a third-line option. Neurostimulation is a fourth-line treatment. Lowdose opioids (no greater than 90 morphine equivalent units) are the fifth-line approach. Finally, a targeted drug delivery is considered as the last option for patients who are resistant to all other therapeutic interventions [6].

Given that the current pharmacological and interventional therapies are not devoid of significant adverse events, there is an urgent need for new, effective, noninvasive therapies.

A growing body of evidence supports the use of hyperbaric oxygen therapy (HBOT) in a number of neuropathic pain conditions with persistent efficacy and minimal adverse events.

HBOT was initially developed to treat decompression sickness, a complication of deep sea diving. In decompression sickness, a diver has surfaced before dissolved gases have time to equilibrate, producing space-occupying embolic nitrogen bubbles in the tissues and vasculature. HBOT provides patients with $100 \%$ oxygen at pressures two to three times greater than atmospheric pressure. According to Boyle's law, the increase of hydrostatic pressure in the hyperbaric chamber elevates the partial pressure of gases and causes a reduction in the volume of the gas-filled spaces, allowing them to dissolve into solution [7]. HBOT also increases partial pressure of oxygen in the alveoli and results in a corresponding increase in the amount of dissolved oxygen carried in blood. During HBOT, the arterial partial pressure of oxygen $\left(\mathrm{PaO}_{2}\right)$ may reach up to $1,900-2,100 \mathrm{mmHg}$, with dissolved oxygen $\left(\mathrm{O}_{2}\right)$ content increasing from 0.3 to $6.8 \mathrm{ml} \mathrm{O}_{2} / 100 \mathrm{ml}$ of blood. This translates to a significant increase in partial pressure of $\mathrm{O}_{2}$ in tissues with compromised circulation [8]. A list of current conditions approved for treatment with HBOT by the Undersea \& Hyperbaric Medicine Society is reflected in Table 3 [9]. For the majority of indications, the HBOT treatments are administered daily for 90-120 minutes for a total of 20-40 consecutive sessions. HBOT is considered a safe, noninvasive therapy with very few side effects (Table 4) [10]. The only absolute contraindication for HBOT is an untreated pneumothorax.

HBOT is an effective treatment of neuropathic pain conditions due to its primary and secondary effects (Figure 1). The primary effects relate to significant increase in partial pressure of tissue $\mathrm{O}_{2}$ (hyperoxia) [8]. Hyperoxia serves as a potential mechanism for treatment of pain conditions with evidence of deep tissue hypoxia, such as in the chronic regional pain syndrome (CRPS) [11, 12]. Increased hydrostatic pressure is another primary effect of HBOT. It induces arteriolar vasoconstriction that reduces formation of tissue edema, without compromising the effect of hyperoxia [13].

The secondary effects of HBOT involve the production of reactive oxygen species (ROS) and reactive nitrogen species (RNS). These reactive species serve as signaling molecules implicated in pain perception, wound healing, angiogenesis, neovascularization, leukocyte function, growth factor, and progenitor stem cell release, as well as tissue homeostasis [8].

Another secondary effect of HBOT is related to reduction in inflammatory mediators.

The objective of this review was to summarize evidence for the mechanistic rationale of HBOT in chronic neuropathic pain conditions and to evaluate its clinical efficacy in this patient population.

\section{Methods}

The methodology used was consistent with the PRISMA Extension for Scoping Reviews Checklist (PRISMA-ScR) [14]. The following databases were searched from January 1946 to March 21, 2020, via the Ovid search interface: Medline, Medline In-Process/ePubs, Embase, Cochrane Central Register of Controlled Trials, Cochrane Database of Systematic Reviews, and PsycINFO. The Web of Science (Clarivate) and Scopus databases, ClinicalTrials.gov (NIH), WHO ICTRP, and ProQuest Digital Dissertation were also included in our search strategy. Search strategy concept blocks were built on the topics of Hyperbaric Oxygen Therapy and Neuropathic Pain, Hyperbaric Oxygen Therapy and Chronic Primary Bladder Pain Syndrome, and Hyperbaric Oxygen Therapy and Complex Regional Pain Syndrome (CRPS). The Medline search strategy is provided in detail in Supplementary Material. We included all articles published or translated in English that involved either animal or human studies with acute or chronic neuropathic pain evaluating any HBOT-related intervention. Study outcomes had to include an assessment of any pain-related or physiologic endpoints, either objective (e.g., cytokine blood levels, imaging, and tissue oxygenation) or subjective (e.g., questionnaires). In order to limit the scope of the review, we excluded studies examining chronic primary headache or orofacial pain (such as migraine, cluster, and tension headaches) and, within the secondary neuropathic pain, the painful diabetic neuropathy, because the abundant literature on these topics over the last four decades would deserve a separate review and is out of the scope of the current analysis. Study selection was performed by two reviewers (SS and JDB) using inclusion and exclusion criteria. The third reviewer (RK) was available to solve any disagreements related to selection process.

\section{Results}

A total of 2971 records were identified through database searching, while 505 references were identified with the search strategy. Furthermore, there were 802 additional 
TABLe 1: Classification of chronic primary pain $[4,5]$.

Diagnostic entity

Chronic widespread pain

CRPS

Chronic primary headache or orofacial pain

Chronic primary visceral pain

Chronic primary musculoskeletal pain
Subcategory

(i) Fibromyalgia

(i) CRPS- 1

(ii) CRPS-2

(i) Chronic migraine

(ii) Chronic tension-type headache

(iii) Trigeminal autonomic cephalalgias

(iv) Chronic primary temporomandibular disorder pains

(v) Burning mouth syndrome

(vi) Chronic primary orofacial pain

(i) Chronic primary chest pain syndrome

(ii) Chronic primary epigastric pain syndrome

(iii) Irritable bowel syndrome

(iv) Chronic primary abdominal pain syndrome

(v) Chronic primary bladder pain syndrome

(vi) Chronic primary pelvic pain syndrome

(i) Chronic primary low back pain

(ii) Chronic primary cervical pain

(iii) Chronic primary thoracic pain

(iv) Chronic primary limb pain

CRPS: chronic regional pain syndrome. Underlined: conditions included in this review.

TABLE 2: Classification of chronic secondary pain syndromes $[3,4]$.

Diagnostic entity Subcategory Syndromes

(i) C. cancer pain

C. cancer-related pain

C. postsurgical or posttraumatic pain

(ii) C. posttraumatic pain

(i) C. peripheral neuropathic pain

C. neuropathic pain

(ii) C. central neuropathic pain

(i) CVP from persistent inflammation

C. secondary visceral pain

(ii) CVP from vascular mechanism

(iii) CVP from mechanical factors

(i) CMSP from persistent inflammation

C. secondary musculoskeletal pain

(ii) CMSP associated with structural changes

(iii) CMSP associated with a disease of the nervous system
C. visceral cancer pain, C. bone cancer pain, C. neuropathic cancer pain Postcancer medicine pain (painful chemo-induced polyneuropathy)

Postradiotherapy pain (C. painful radiation-induced neuropathy)

$\mathrm{CP}$ after amputation, $\mathrm{CP}$ after spinal surgery, $\mathrm{CP}$ after thoracotomy, $\mathrm{CP}$ after breast surgery, $\mathrm{CP}$ after herniotomy, CP after hysterectomy, CP after arthroplasty

CP after burns injury, CP after peripheral nerve injury (i.e., CRPS Type 2), $\mathrm{CP}$ after spinal cord injury, $\mathrm{CP}$ after brain injury, $\mathrm{CP}$ after whiplash injury, $\mathrm{CP}$ after musculoskeletal injury

Trigeminal neuralgia, chronic neuropathic pain after peripheral nerve injury, painful polyneuropathy, postherpetic neuralgia, painful radiculopathy (including chemo- or radio-induced)

CCNP associated with spinal cord injury, CCNP associated with brain injury, C central poststroke pain, CCNP associated with multiple sclerosis

$\mathrm{CH}$ or COP attributed to trauma or injury to the head or neck (e.g., CP after whiplash injury), $\mathrm{CH}$ or $\mathrm{COP}$ attributed to cranial or cervical vascular disorder, $\mathrm{CH}$ or $\mathrm{COP}$ attributed to nonvascular intracranial disorder, $\mathrm{CH}$ attributed to a substance or its withdrawal, $\mathrm{CH}$ or $\mathrm{COP}$ attributed to infection, $\mathrm{CH}$ attributed to disorders of homoeostasis or their nonpharmacological treatment, $\mathrm{CH}$ or $\mathrm{COP}$ attributed to disorder of the cranium, neck, eyes, ears, sinuses, salivary glands, oral mucosa, C. dental pain (e.g., attributed to irreversible pulpitis, or attributed to symptomatic apical periodontitis), C. neuropathic orofacial pain (e.g., $\mathrm{TN}$ or other cranial neuralgias), $\mathrm{CH}$ or $\mathrm{COP}$ attributed to chronic secondary temporomandibular disorders (e.g., chronic secondary orofacial muscle pain)

Each one could be in the head or neck region, in the thoracic region, in the abdominal region, in the pelvic region

(i) Due to infection, due to crystal deposition, due to autoimmune and autoinflammatory disorders

(ii) CMSP associated with osteoarthritis, CMSP associated with spondylosis, CP after musculoskeletal injury

(iii) CMSP associated with Parkinson's diseases, CMSP associated with multiple sclerosis, CMSP associated with peripheral neurologic disease

C.: chronic, CRPS: chronic regional pain syndrome, CP: chronic pain, CCNP: chronic central neuropathic pain, CH: chronic headache, COP: chronic orofacial pain, and CVP: chronic visceral pain, CMSP: chronic musculoskeletal pain. Underlined: conditions included in this review. 
TABLE 3: HBOT indications [9].

Indications for hyperbaric oxygen therapy

Air or gas embolisms

Carbon monoxide poisoning

Clostridial myositis and myonecrosis

Crush injury, compartment syndrome and other acute traumatic ischemia

Decompression sickness

Arterial insufficiencies (central retinal artery occlusion, enhancement of healing in selected problem wounds)

Severe anemia

Intracranial abscess

Necrotizing soft tissue infections

Refractory osteomyelitis

Delayed radiation injury (soft tissue and bony necrosis)

Acute thermal burn injury

Idiopathic sudden sensorineural hearing loss

TABLE 4: Side effects of hyperbaric oxygen therapy [10].

Middle ear barotrauma, sinus squeeze, claustrophobia, progressive myopia, pulmonary barotrauma, seizures

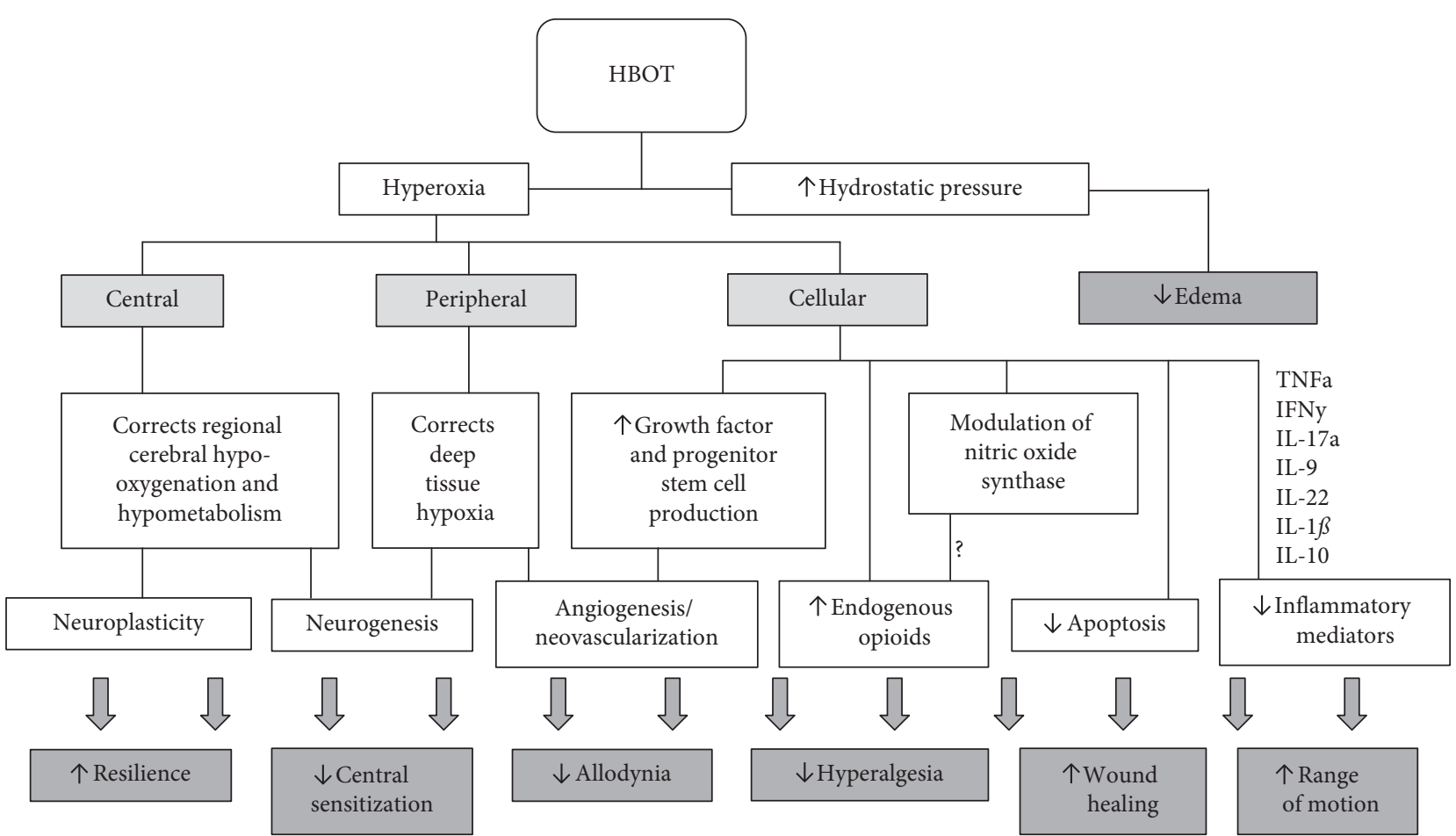

FIGURE 1: HBOT mechanisms and effect on chronic neuropathic pain disorders. HBOT: hyperbaric oxygen therapy; ROS: reactive oxygen species; RNS: reactive nitrogen species; TNF $\alpha$ : tumor necrosis factor-alpha; IFN $\gamma$ : interferon-gamma; IL: interleukin.

records through other sources, including 433 Citation Searching and 322 dissertations. 1436 duplicates were identified and removed by the specific Covidence software tool. After 2337 records were screened, 2201 were excluded. A total of 136 references met the inclusion criteria. 107 records were excluded. Finally, 29 studies were included in the qualitative synthesis (Figure 2, PRISMA flow diagram).

3.1. HBOT in Animal Models of Neuropathic Pain. Animal models for both neuropathic and inflammatory pain conditions demonstrate the antiallodynic and antinociceptive effects of HBOT through a wide range of treatment regimens.

The most common animal model for neuropathic pain is a chronic constriction injury (CCI) to the sciatic nerve. In this model investigators tie four ligatures around the sciatic nerve to create intraneural edema and ischemia, neuronal apoptosis, and Wallerian degeneration [15]. Shortly after CCI, rats exhibit neuropathic pain behaviors including mechanical, chemical, and thermal hyperalgesia and allodynia persisting for up to two months [15]. Other painrelated characteristics including appetite suppression, nocifensive behaviors (scratching, biting, self-mutilation), 


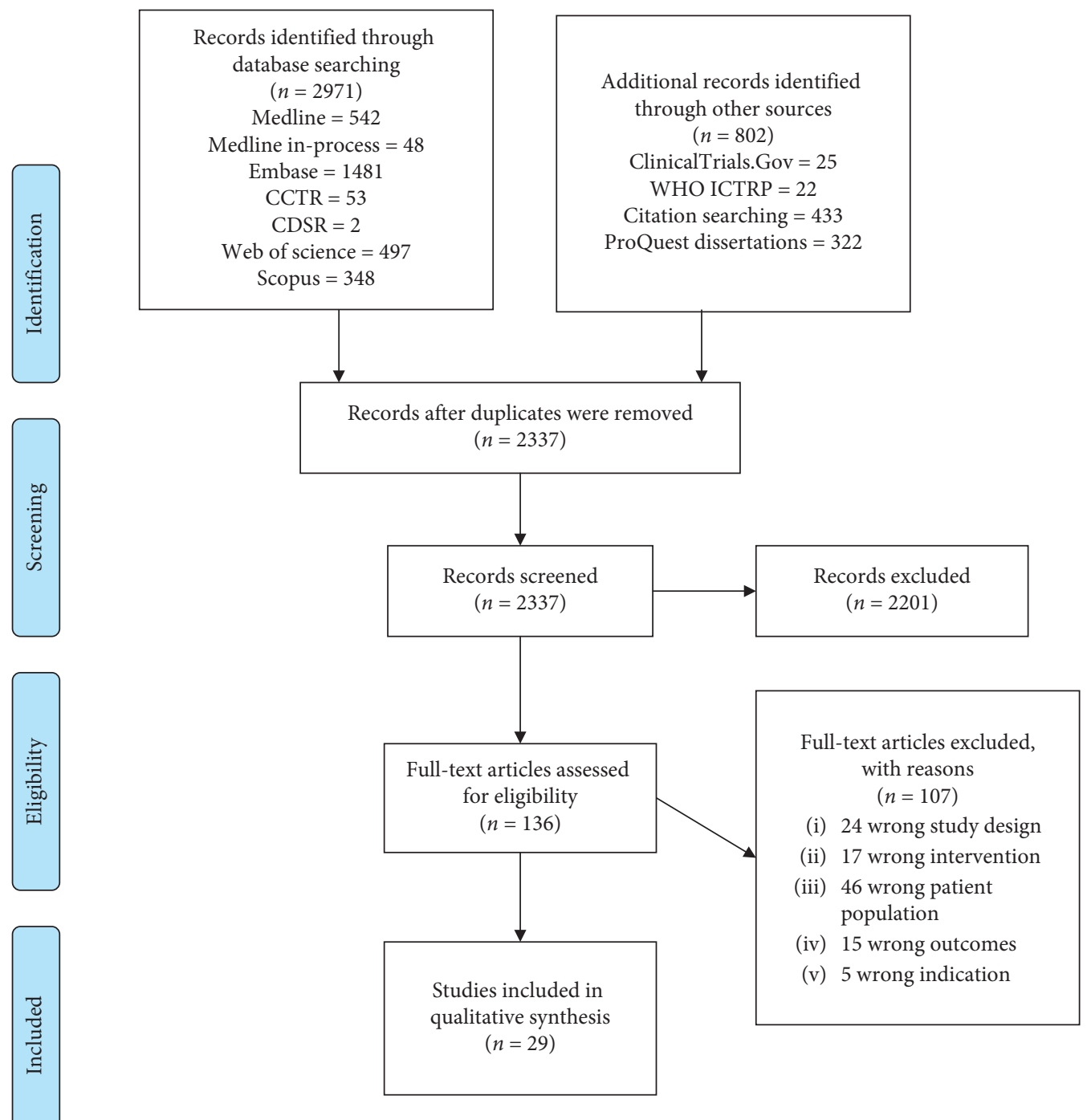

FIgURE 2: PRISMA flow diagram.

and increased anxiety- and depression-like behaviors following CCI implicate cognitive and affective sequalae of this neuropathic pain model [16]. Table 5 summarizes 9 animal studies of neuropathic pain that all demonstrate the efficacy of HBOT, across a wide spectrum of treatment regimens, in reducing the thermal and mechanical hyperalgesia and allodynia induced by experimental nerve injury [17-25]. While some of these studies demonstrate sustained (up to one month) antiallodynic and antinociceptive effects with only one HBOT session, the majority of studies suggest a dose-response with sustained therapeutic benefit after multiple consecutive HBOT sessions. Suggested mechanisms for the therapeutic effects of HBOT in this animal model include inhibition or suppression of CCI-induced inflammation [17, 18, 22], neuronal apoptosis [21, 25], and increased expression of endogenous opioids [20]. CCIinduced expression of nitric oxide synthase isoforms, which are involved in the modulation of periphery and central nociceptive pathways, are also attenuated following HBOT $[23,24]$.
Animal studies have also suggested potential benefits of HBOT in chemotherapy-induced neuropathic pain. In one study [26], 7-day exposure to paclitaxel induced mechanical and cold allodynia in rats. After 1-4 treatments of HBOT, mechanical allodynia was completely reversed, while cold allodynia was not reliably reduced. Another study [27] examined the effects of HBOT as a treatment and prophylaxis in cisplatin-induced peripheral neuropathy. After twice-weekly intraperitoneal injections of cisplatin over a period of four weeks, mechanical allodynia was observed in rats following the first week of cisplatin exposure and persisting throughout the three following weeks. A 7-day HBOT treatment course following 4 weeks of cisplatin exposure did not improve the mechanical nociceptive threshold; however the 7-day HBOT treatment course before the 4 weeks of cisplatin exposure did significantly improve mechanical allodynia. In this "preconditioning" group, the antinociceptive benefit of HBOT was attributed to decreased apoptosis and inflammation. Immunohistochemical analysis of the sciatic nerve and associated ganglia demonstrated 


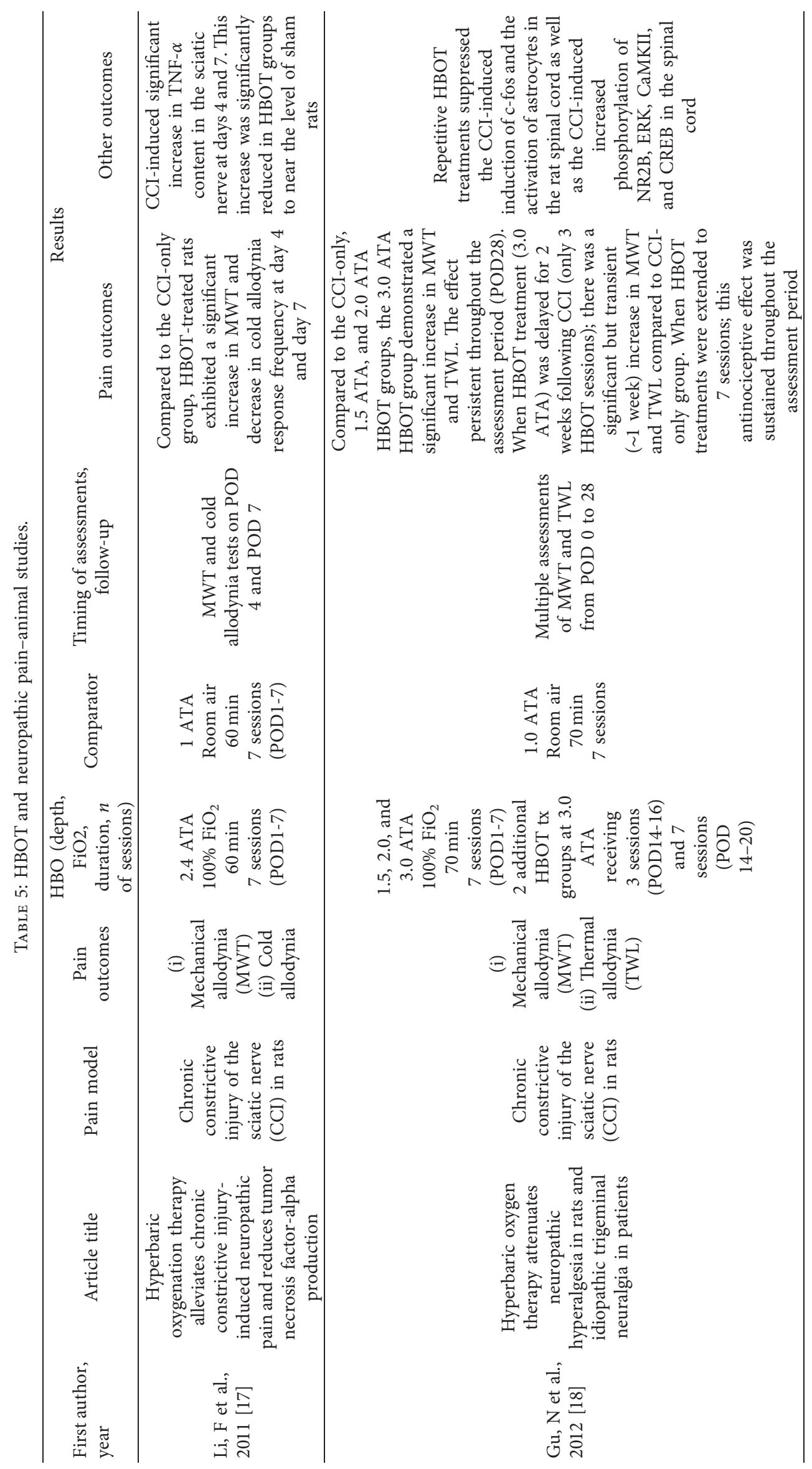




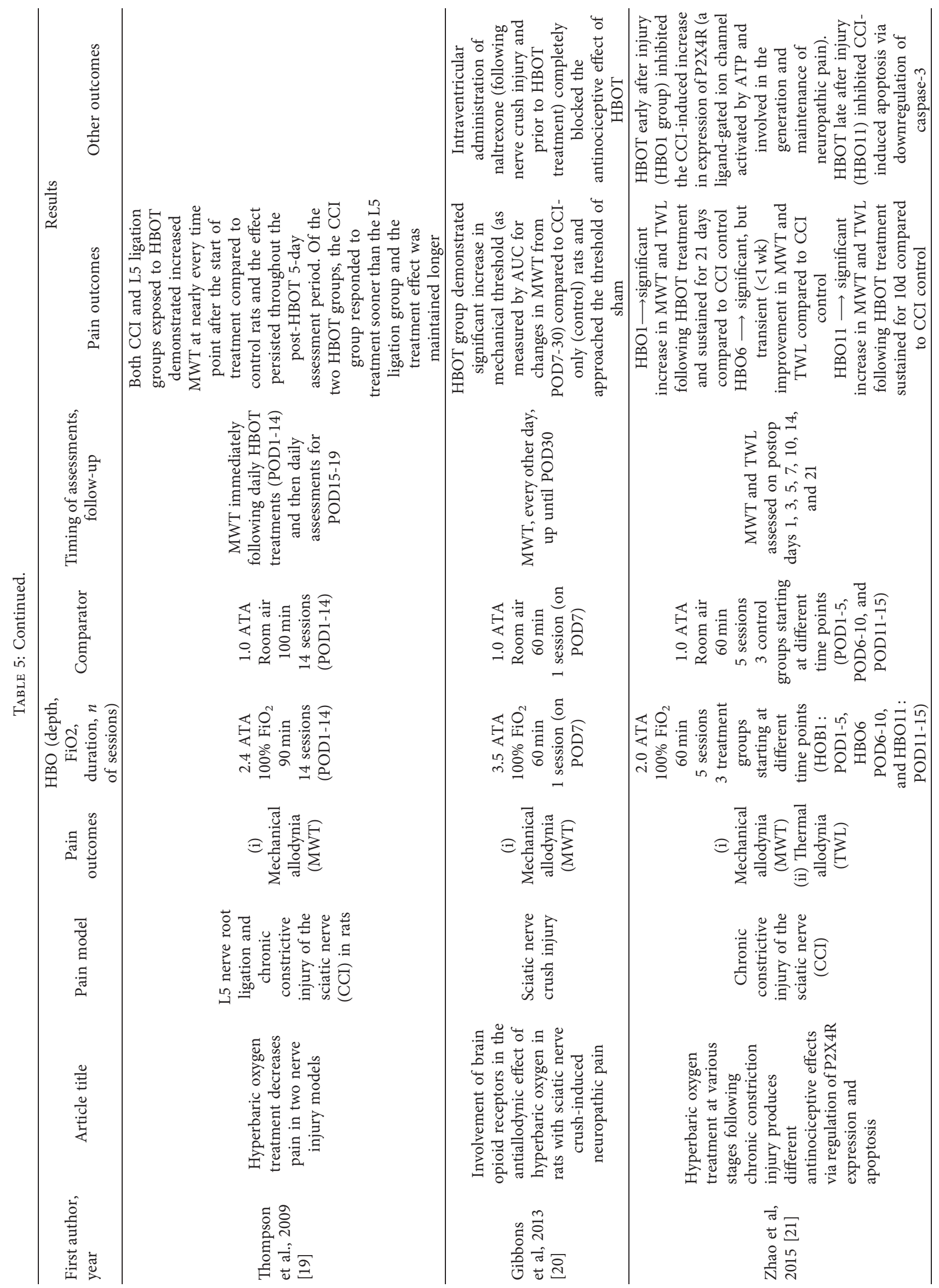




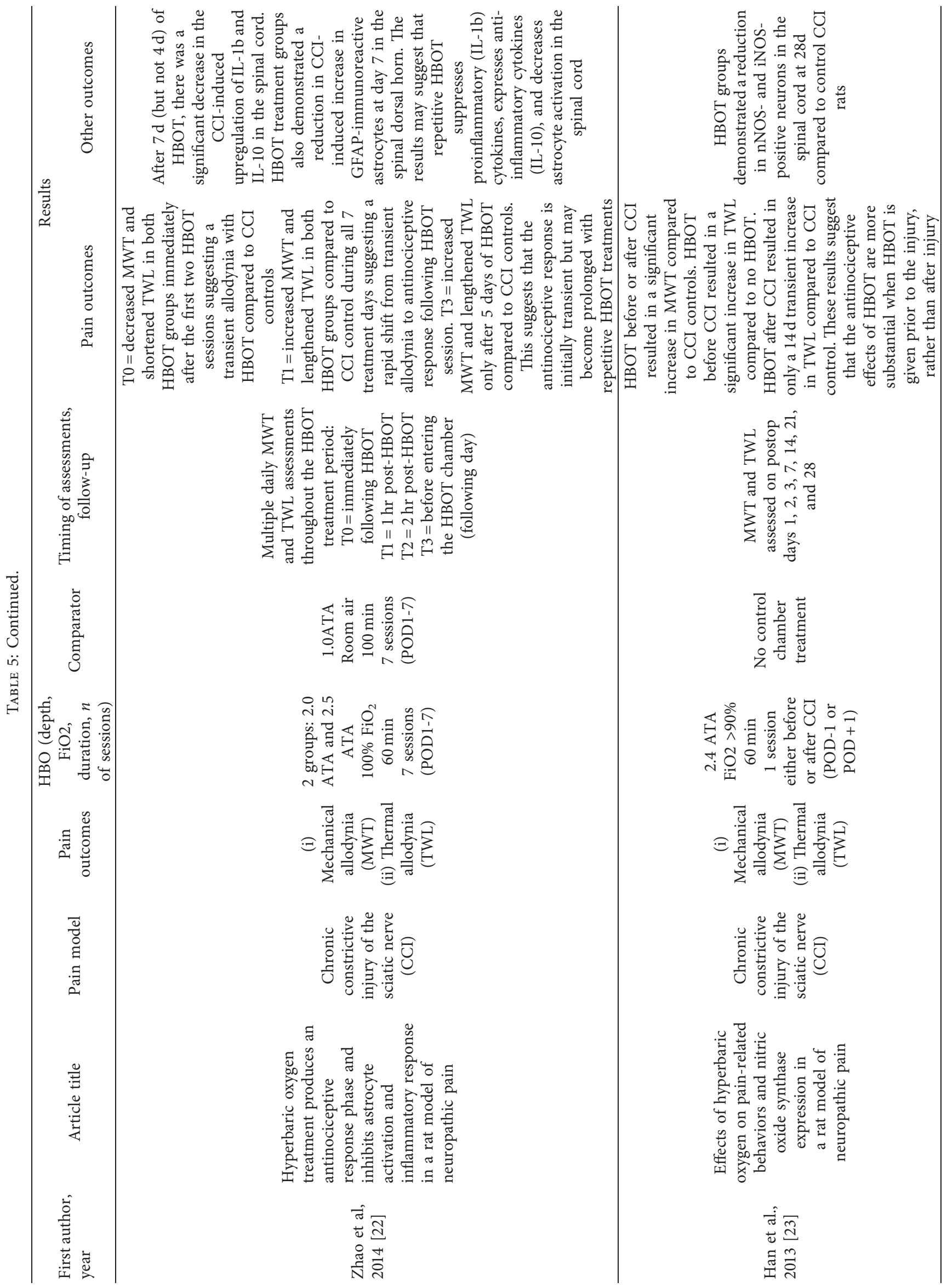




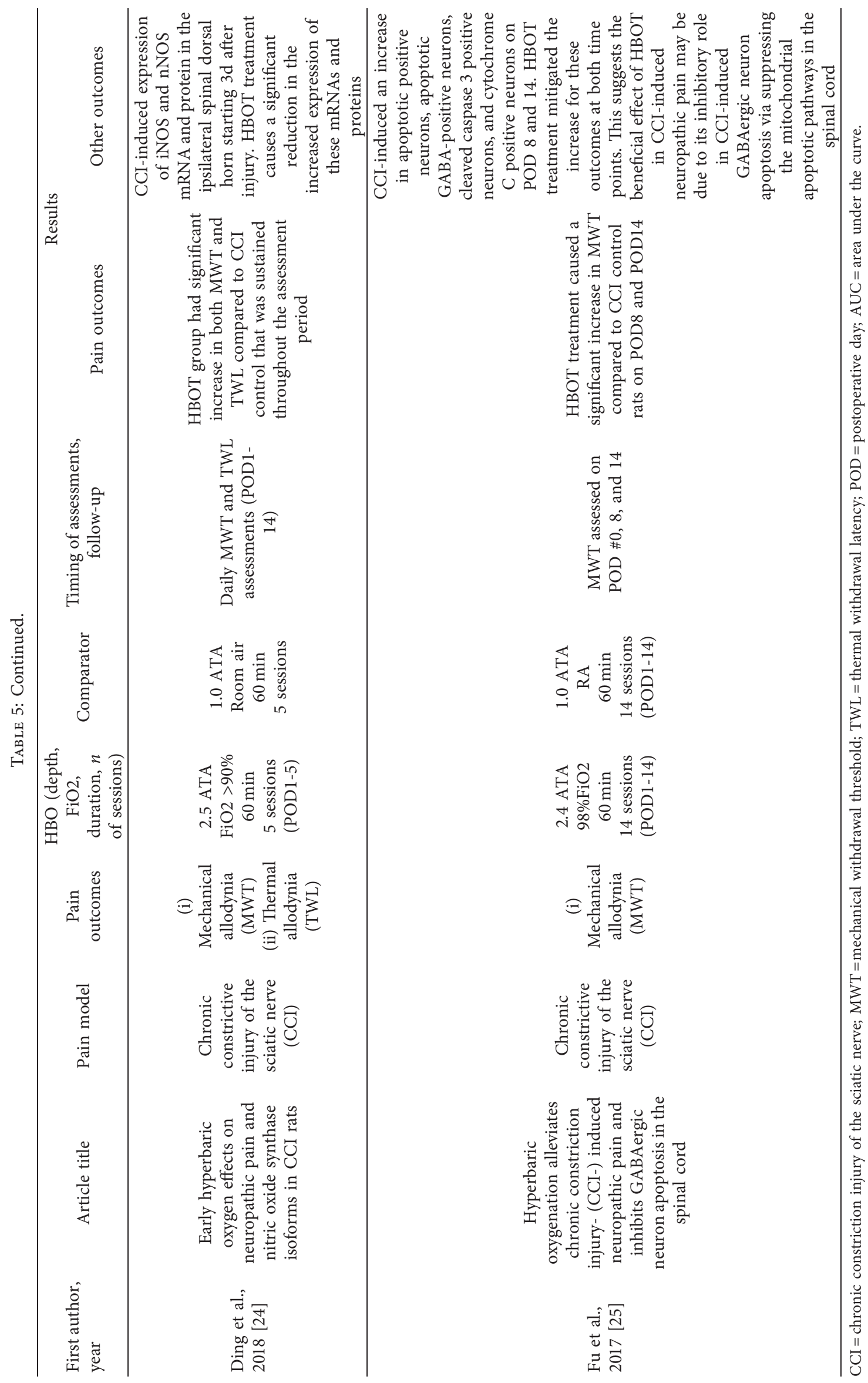


decreased upregulation of caspase- 3 expression (proapoptotic mediator) and an attenuated expression of TNF- $\alpha$ and inducible NOS expression when compared to the control group. In combination with the CCI-model of neuropathic pain, these animal studies further validated some of the proposed antiallodynic and antinociceptive mechanisms of HBOT.

Hyperoxygenation serves as a potential mechanism for treatment of neuropathic pain conditions that show evidence of deep tissue hypoxia, such as in chronic regional pain syndrome (CRPS) [11, 12]. The deep tissue hypoxia hypothesis has been tested in the animal model of ischemia and reperfusion related chronic pain. Known as "chronic postischemia pain," a tourniquet is placed around a rat's ankle for 3 hours under general anesthesia and then released. After reperfusion, the hind paw exhibits an initial phase of hyperemia and edema lasting for 2-12 hours, followed by neuropathic pain (mechano-hyperalgesia, mechano-allodynia, and cold allodynia) that lasts for at least one month [28]. Using this ischemia-reperfusion model, Coderre et al. [11] discovered microvascular injury in the capillaries of deep muscles and nerves. Their findings implicated deep tissue and endoneurial ischemia and inflammation in the activation of both muscle nociceptors and ectopic sensory afferent axons [11]. The efficacy of HBOT, however, has not yet been tested in this animal model. The deep tissue hypoxia hypothesis for chronic pain also extends to the central nervous system. This is because regional, cerebral hypoperfusion and hypometabolism have been associated with chronic pain conditions, such as fibromyalgia and CRPS [29-31]. HBOT appears to correct or rectify these regional differences in brain perfusion and metabolism, inducing changes that are associated with reduction in pain symptoms and improved quality of life [32].

Increased hydrostatic pressure is another primary effect of HBOT. HBOT induces arteriolar vasoconstriction by subsequently reducing tissue edema formation, without compromising the supernormal tissue $\mathrm{pO}_{2}$ [13]. This mechanism may contribute to a reduction in symptoms in patients with chronic pain conditions where tissue edema and inflammation are the primary components [33]. An animal model of inflammatory pain and edema has tested this theory. A subcutaneous injection of $1 \%$ carrageenan substance into rats' hind paws induced both mechanical hyperalgesia and edema providing a close clinical surrogate to inflammatory pain in humans [28]. Mechanical hyperalgesia or hypersensitivity was measured using the "mechanical paw withdrawal threshold (MPWT)," whereby von Frey filaments of increasing diameter (increasing force) poked the animals' hind paws through a mesh cage. Compared to sham group, HBOT-treated rats exhibited decreased mechanical hyperalgesia/hypersensitivity (a higher MPWT) almost immediately following treatment. There was also evidence for the decreased edema formation after HBOT; however, it lagged slightly behind the antinociceptive effect [28].

Secondary effects of HBOT that may underlie the treatment of chronic pain disorders involve the production of ROS and RNS. In animal models for neuropathic pain, the therapeutic effect for HBOT involves a reduction or attenuation of CCI-induced nitric oxide synthase expression $[23,24]$. However, in experimental models of abdominal pain the opposite is shown $[29,31]$.

Zelinski et al. [29] sought to elucidate the mechanism underlying the antinociceptive effect of HBOT in their animal model of chronic pain. Following intraperitoneal injection of $0.6 \%$ glacial acetic acid, mice exhibited abdominal constrictions (lengthwise stretches of the torso with concave arching of the back), presumed to be a pain response that was quantifiable (number of constrictions). HBOT showed a profound reduction in abdominal constrictions compared to those in the untreated mice [29].

In search of a mechanistic explanation for the antinociceptive effect of HBOT in this model the group hypothesized a neural nitric oxide- (NO-) dependent mechanism as it was known that HBOT increased cerebral blood flow and RNS production through neural NO synthase (nNOS) activation in the cerebral cortex [30]. They discovered that central administration (intracerebroventricular or intrathecal) of NOS enzyme inhibitors and antisense oligodeoxynucleotides against nNOS attenuated HBOT-mediated analgesia in mice. A similar attenuation was noted in nNOS knockout mice and with naltrexone (opioid antagonist) administration [29, 31]. While both neuropathic and abdominal/inflammatory models of pain demonstrate the release of endogenous opioids as a therapeutic mechanism, the pro- or antinociceptive role of NOS and RNS remains controversial [34] and may vary at different locations within the central and peripheral nervous system as well as with different etiology of chronic pain.

\subsection{HBOT in Human Studies of Neuropathic Pain}

3.2.1. HBOT in Complex Regional Pain Syndrome. A total of 5 case reports and one RCT described effects of HBOT in CRPS patients (Tables 6 and 7).

CRPS is a chronic primary pain syndrome characterized by spontaneous and/or evoked pain disproportionate to the typical course of pain produced from a similar inciting event. The pain distribution is not limited to specific nerve territory or dermatome and often has a distal spread. It can be accompanied by sensory (hyperalgesia/allodynia), vasomotor, sudomotor/edema, and motor/trophic changes [47]. CRPS is caused by a multifactorial process involving both peripheral and central mechanisms as well as sensitization. Inflammatory and immune-related factors, altered sympathetic nervous system function, ischemic reperfusion injury, and oxidative stress are among the many possible mechanisms implicated in CRPS [48, 49]. In addition to anti-inflammatory activity $[17,28]$, four possible mechanisms are proposed to account for the improvement in symptoms and quality of life that is seen following HBOT in CRPS patients.

\subsubsection{HBOT and Reduction of Deep Tissue Hypoxia.} Bellingham et al. [12] demonstrated that deep tissue oxygen saturation $\left(\mathrm{StO}_{2}\right)$ was significantly lower in the affected limb of patients with CRPS compared to either the nonaffected 
TABLE 6: HBOT and neuropathic pain-human studies characteristics.

\begin{tabular}{|c|c|c|c|c|c|c|}
\hline $\begin{array}{l}\text { First author, } \\
\text { year }\end{array}$ & Article title & Pain model & $\begin{array}{l}\text { Study design, } n \\
\text { patients }\end{array}$ & Inclusion criteria & $\begin{array}{c}\text { Intervention (HBOT } \\
\text { pressure, duration, } n \text { of } \\
\text { sessions) }\end{array}$ & $\begin{array}{l}\text { Comparator/ } \\
\text { control }\end{array}$ \\
\hline $\begin{array}{l}\text { Kiralp, } 2004 \\
\text { [33] }\end{array}$ & $\begin{array}{c}\text { Effectiveness of } \\
\text { hyperbaric oxygen } \\
\text { therapy in the treatment } \\
\text { of complex regional pain } \\
\text { syndrome }\end{array}$ & CRPS & $\begin{array}{l}\mathrm{RCT}, n=71(37 \\
\text { intervention, } 34 \\
\text { placebo) }\end{array}$ & $\begin{array}{c}\text { Clinical CRPS, type } \\
\text { I or II }\end{array}$ & 2.4 ATA, $90 \min \times 15$ & $\begin{array}{l}\text { Placebo: } 2.4 \\
\text { ATA breathing } \\
\text { air, } 90 \text { min x } 15 \text {, } \\
\text { once daily }\end{array}$ \\
\hline $\begin{array}{l}\text { Peach, } 1995 \\
{[35]}\end{array}$ & $\begin{array}{l}\text { Hyperbaric oxygen and } \\
\text { the reflex sympathetic } \\
\text { dystrophy syndrome: a } \\
\text { case report }\end{array}$ & CRPS & $\begin{array}{c}\text { Observational } \\
\text { case reports, } n=1\end{array}$ & $\begin{array}{c}\text { Clinical CRPS, type } \\
\text { I }\end{array}$ & $\begin{array}{c}2.8 \text { ATA, } 46 \min \\
x 1+2.0 \text { ATA, } \\
90 \min \times 1+2.4 \text { ATA, } \\
90 \min \times 1\end{array}$ & None \\
\hline $\begin{array}{l}\text { Williams, } \\
2009[36]\end{array}$ & $\begin{array}{l}\text { Chronic regional pain } \\
\text { syndrome after subtalar } \\
\text { arthrodesis is not } \\
\text { prevented by early } \\
\text { hyperbaric oxygen }\end{array}$ & CRPS & $\begin{array}{c}\text { Observational } \\
\text { case reports, } n=1\end{array}$ & $\begin{array}{l}\text { Clinical CRPS type } \\
\text { I, Norman Harden } \\
\text { and Bruehl } \\
\text { diagnostic criteria }\end{array}$ & 2.2 ATA, $90 \min \times 19$ & None \\
\hline $\begin{array}{l}\text { Katznelson, } \\
2016 \text { [37] }\end{array}$ & $\begin{array}{l}\text { Successful treatment of } \\
\text { lower limb complex } \\
\text { regional pain syndrome } \\
\text { following three weeks of } \\
\text { hyperbaric oxygen } \\
\text { therapy }\end{array}$ & CRPS & $\begin{array}{c}\text { Observational } \\
\text { case reports, } n=1\end{array}$ & $\begin{array}{c}\text { Clinical CRPS, type } \\
\text { I }\end{array}$ & 2.4 ATA, $90 \min \times 15$ & None \\
\hline $\begin{array}{l}\text { Binkley, } 2019 \\
{[38]}\end{array}$ & $\begin{array}{l}\text { Successful treatment of } \\
\text { long standing complex } \\
\text { regional pain syndrome } \\
\text { with hyperbaric oxygen } \\
\text { therapy }\end{array}$ & CRPS & $\begin{array}{c}\text { Observational } \\
\text { case reports, } n=1\end{array}$ & $\begin{array}{l}\text { Clinical CRPS, type } \\
\text { I }\end{array}$ & $\begin{array}{c}2.4 \text { ATA, } 90 \min \times 40 \text {. } \\
\text { Second course } 7 \\
\text { months later, } 2.0 \text { ATA, } \\
90 \min \times 33 \text {. }\end{array}$ & None \\
\hline $\begin{array}{l}\text { van } \\
\text { Ophoven, } \\
2004[39]\end{array}$ & $\begin{array}{l}\text { Hyperbaric oxygen for the } \\
\text { treatment of interstitial } \\
\text { cystitis: long-term results } \\
\text { of a prospective pilot } \\
\text { study }\end{array}$ & IC & $\begin{array}{l}\text { Observational } \\
\text { prospective case } \\
\text { series, } n=6\end{array}$ & $\begin{array}{l}\text { Symptom criteria } \\
\text { of the National } \\
\text { Institute of } \\
\text { Diabetes, Digestive } \\
\text { and Kidney } \\
\text { Diseases for IC }\end{array}$ & 2.4 ATA, $90 \min \times 30$ & None \\
\hline $\begin{array}{l}\text { van } \\
\text { Ophoven, } \\
2006[40]\end{array}$ & $\begin{array}{l}\text { Safety and efficacy of } \\
\text { hyperbaric oxygen } \\
\text { therapy for the treatment } \\
\text { of interstitial cystitis: A } \\
\text { randomized, sham } \\
\text { controlled, double-blind } \\
\text { trial }\end{array}$ & IC & $\begin{array}{l}\text { RCT, double- } \\
\text { blind, sham } \\
\text { controlled, } n=21 \\
\text { (14 intervention, } 7 \\
\text { placebo) }\end{array}$ & $\begin{array}{l}\text { Diagnostic criteria } \\
\text { of the National } \\
\text { Institute of } \\
\text { Diabetes and } \\
\text { Digestive and } \\
\text { Kidney Diseases } \\
\text { for IC }\end{array}$ & $2.4,90 \min \times 30$ & $\begin{array}{l}\text { Placebo: } 1.3 \\
\text { ATA breathing } \\
\text { air, } 90 \text { min } \times 30 \text {, } \\
\text { once daily }\end{array}$ \\
\hline $\begin{array}{l}\text { Tanaka, } 2011 \\
{[41]}\end{array}$ & $\begin{array}{r}\text { Hyperbaric oxygen } \\
\text { therapy for painful } \\
\text { bladder syndrome/ } \\
\text { interstitial cystitis } \\
\text { resistant to conventional } \\
\text { treatments: long-term } \\
\text { results of a case series in } \\
\text { Japan }\end{array}$ & IC & $\begin{array}{r}\text { Observational } \\
\text { prospective case } \\
\text { series, } n=11\end{array}$ & $\begin{array}{r}\text { Diagnostic criteria } \\
\text { of the National } \\
\text { Institute of } \\
\text { Diabetes and } \\
\text { Digestive and } \\
\text { Kidney Diseases } \\
\text { for IC }\end{array}$ & $\begin{array}{r}2.0 \mathrm{ATA}, 60 \min \times 10(8 \\
\text { pts) or } \mathrm{x} 20(3 \mathrm{pts})\end{array}$ & None \\
\hline $\begin{array}{l}\text { Wenzler, } \\
2017[42]\end{array}$ & $\begin{array}{l}\text { Treatment of ulcerative } \\
\text { compared to } \\
\text { nonulcerative interstitial } \\
\text { cystitis with hyperbaric } \\
\text { oxygen: a pilot study }\end{array}$ & IC & $\begin{array}{l}\text { Observational } \\
\text { prospective pilot } \\
\text { case series, } n=9\end{array}$ & $\begin{array}{l}\text { Diagnostic criteria } \\
\text { of the National } \\
\text { Institute of } \\
\text { Diabetes and } \\
\text { Digestive and } \\
\text { Kidney Diseases } \\
\text { for IC }\end{array}$ & 2.2 ATA, $90 \min \times 30$ & None \\
\hline
\end{tabular}


TABle 6: Continued.

\begin{tabular}{|c|c|c|c|c|c|c|}
\hline $\begin{array}{l}\text { First author, } \\
\text { year }\end{array}$ & Article title & Pain model & $\begin{array}{l}\text { Study design, } n \\
\text { patients }\end{array}$ & Inclusion criteria & $\begin{array}{c}\text { Intervention (HBOT } \\
\text { pressure, duration, } n \text { of } \\
\text { sessions) }\end{array}$ & $\begin{array}{c}\text { Comparator/ } \\
\text { control }\end{array}$ \\
\hline $\begin{array}{l}\text { Pritchard, } \\
2011 \text { [43] }\end{array}$ & $\begin{array}{l}\text { Double-blind randomized } \\
\text { phase II study of } \\
\text { hyperbaric oxygen in } \\
\text { patients with radiation- } \\
\text { induced brachial } \\
\text { plexopathy }\end{array}$ & RIBP & $\begin{array}{l}\text { RCT, double- } \\
\text { blind, sham } \\
\text { controlled, } n=34 \\
\text { (17 intervention, } \\
17 \text { placebo) }\end{array}$ & $\begin{array}{l}\text { Confirmation of } \\
\text { RIBP, freedom } \\
\text { from cancer } \\
\text { recurrence, fitness } \\
\text { for HBOT }\end{array}$ & $2.4 \mathrm{ATA}, 90 \min \times 30$ & $\begin{array}{l}\text { Placebo: } 2.4 \\
\text { ATA breathing } \\
41 \% \text { oxygen, } \\
90 \text { min } x 30\end{array}$ \\
\hline
\end{tabular}

\begin{tabular}{|c|c|c|c|c|c|c|}
\hline $\begin{array}{l}\text { Videtic, } 1999 \\
{[44]}\end{array}$ & $\begin{array}{c}\text { Hyperbaric oxygen } \\
\text { corrects sacral plexopathy } \\
\text { due to osteoradionecrosis } \\
\text { appearing } 15 \text { years after } \\
\text { pelvic irradiation }\end{array}$ & $\begin{array}{c}\text { Sacral } \\
\text { plexopathy }\end{array}$ & $\begin{array}{c}\text { Observational } \\
\text { case reports, } n=1\end{array}$ & Clinical diagnosis & 2.5 ATA, $90 \min \times 30$ & None \\
\hline $\begin{array}{l}\text { Stowe, } 2020 \\
{[45]}\end{array}$ & $\begin{array}{l}\text { Hyperbaric oxygen } \\
\text { therapy for radiation- } \\
\text { induced brachial } \\
\text { plexopathy, a case report } \\
\text { and literature review }\end{array}$ & RIBP & $\begin{array}{c}\text { Observational } \\
\text { case reports, } n=1\end{array}$ & $\begin{array}{l}\text { Clinical and } \\
\text { radiographic } \\
\text { diagnosis }\end{array}$ & 2.4 ATA, $120 \min \times 30$ & None \\
\hline $\begin{array}{l}\text { Peng, } 2012 \\
{[46]}\end{array}$ & $\begin{array}{l}\text { Effect of hyperbaric } \\
\text { oxygen therapy on } \\
\text { patients with herpes } \\
\text { zoster }\end{array}$ & PHN & $\begin{array}{c}\text { RCT, not blinded, } \\
n=68(36 \\
\text { intervention, } 32 \\
\text { control) }\end{array}$ & $\begin{array}{c}\text { Clinical diagnosis } \\
\text { of acute herpes } \\
\text { zoster }\end{array}$ & $\begin{array}{l}\text { 2.2 ATA, } 80 \text { min } x 30 \text {, } \\
\text { twice a day + medical } \\
\text { therapy [antiviral } \\
\text { (acyclovir), nerve } \\
\text { nutritive } \\
\text { (mecobalamin), pain } \\
\text { relief (tramadol), and } \\
\text { antidepressive } \\
\text { (nortriptyline)] }\end{array}$ & $\begin{array}{l}\text { Controls: only } \\
\text { medical } \\
\text { therapy }\end{array}$ \\
\hline Gu, 2012 [18] & $\begin{array}{c}\text { Hyperbaric oxygen } \\
\text { therapy attenuates } \\
\text { neuropathic hyperalgesia } \\
\text { in rats and idiopathic } \\
\text { trigeminal neuralgia in } \\
\text { patients }\end{array}$ & $\mathrm{TN}$ & $\begin{array}{c}\text { RCT, } n=42(22 \\
\text { intervention, } 20 \\
\text { placebo) }\end{array}$ & $\begin{array}{l}\text { Clinical diagnosis } \\
\text { of idiopathic TN }\end{array}$ & $1.8 \mathrm{ATA}, 70 \min \mathrm{x} 10$ & $\begin{array}{l}\text { Placebo: } 1.03 \\
\text { ATA breathing } \\
\text { air, } 70 \text { min x } 10\end{array}$ \\
\hline
\end{tabular}

$n=$ number; HBOT $=$ hyperbaric oxygen therapy; $\mathrm{CRPS}=$ chronic regional pain syndrome; $\mathrm{IC}=$ interstitial cystitis; RIBP= radiation-induced brachial plexopathy; $\mathrm{PHN}=$ postherpetic neuralgia; $\mathrm{TN}=$ trigeminal neuralgia; $\mathrm{RCT}=$ randomized controlled trial.

limb or healthy volunteers. Given that HBOT significantly increases $\mathrm{StO}_{2}$ [50], the "deep tissue hypoxia" theory is an attractive mechanism for the proposed benefit of HBOT, although the changes in $\mathrm{StO}_{2}$ before and after HBOT have not been documented in patients with CRPS. Improved tissue oxygenation was the suspected mechanism in the first report of HBOT benefit in a CRPS patient. A case study from 1995 [35] reported a 44-year-old woman with CRPS treated with emergent HBOT for acute smoke inhalation for 46 minutes at 2.8 ATA. 15 minutes after the start of the therapy the patient "reported relief of pain in her foot" that appeared "less cyanotic and warmer to the touch." The foot color remained pink for 8 hours and painless for 18 hours after the first HBOT session. The patient was offered a second 90-minute HBOT session at 2.0 ATA with mild symptom improvement (the foot remained pink for 1 hour and painless for 2 hours after HBOT) and one additional session at 2.4 ATA, with marked and long-lasting relief (the foot was pink and painless for 30 hours after HBOT). While no precise methodology for assessment was reported, the clinical findings were thought to be related to improved perfusion and oxygenation with the corresponding improvement in pain control.
3.2.3. HBOT and Reduction of Tissue Edema. A second potential mechanism of HBOT is related to decreased tissue edema, which is a common feature of CRPS. It is well described that HBOT causes vasoconstriction and decreases edema $[13,33]$. It is suggested that the hyperoxic environment leads to increased oxidation of NO radicals produced by the endothelium and a loss of the vasorelaxant effect [51], alterations in other vasodilator compounds (i.e., prostaglandins) [52], and stimulation of central vasoregulation via the sympathetic nervous system [53]. Indeed, an RCT of patients with CRPS [33] demonstrated improved range of motion and decreased edema following HBOT. In this double-blind RCT, 71 patients with posttraumatic wrist CRPS were randomized to a treatment group (37 patients), receiving $15 \mathrm{HBOT}$ sessions, 90 minutes each at 2.4 ATA, or a control group (34 patients) that received 15 placebo sessions in the hyperbaric chamber, 90-minute each breathing normal air at 2.4 ATA. In addition to HBOT, all patients received paracetamol $500 \mathrm{mg}$ three times a day but did not receive any physical therapy during the study. Assessments included evaluation of visual analogue pain scores, range of motion (goniometric assessment of wrist flexion and 
TABLE 7: Effect of HBOT on neuropathic pain patient outcomes.

\begin{tabular}{|c|c|c|c|c|c|}
\hline \multirow{2}{*}{$\begin{array}{l}\text { First author, } \\
\text { year, pain } \\
\text { model } \\
\text { ( } n \text { patients })\end{array}$} & \multirow[b]{2}{*}{ Outcomes } & \multirow{2}{*}{$\begin{array}{l}\text { Timing of } \\
\text { assessments and } \\
\text { follow-up }\end{array}$} & \multicolumn{2}{|c|}{ Results } & \multirow[b]{2}{*}{ Remarks and safety } \\
\hline & & & $\begin{array}{l}\text { Subjective clinical } \\
\text { outcomes }\end{array}$ & $\begin{array}{l}\text { Objective clinical } \\
\text { outcomes }\end{array}$ & \\
\hline $\begin{array}{l}\text { Kiralp, 2004, } \\
\text { [33]CRPS } \\
(n=71)\end{array}$ & $\begin{array}{l}\text { Clinical (pain (VAS), range } \\
\text { of motion (ROM), edema } \\
\text { (wrist circumference)) }\end{array}$ & $\begin{array}{c}\text { Before and after } \\
\text { HBOT, } 45 \text { days } \\
\text { F/U }\end{array}$ & $\begin{array}{l}\text { Intervention: lower } \\
\text { pain }(p<0.001) ; \\
\text { placebo: no } \\
\text { improvements }\end{array}$ & $\begin{array}{l}\text { Intervention: increased } \\
\text { ROM and decreased } \\
\text { edema }(p<0.001) . \\
\text { Placebo: no } \\
\text { improvements }\end{array}$ & $\begin{array}{l}\text { Placebo received } \\
\text { therapeutic oxygen dose }\end{array}$ \\
\hline $\begin{array}{l}\text { Peach, 1995, } \\
\text { [35] CRPS } \\
(n=1)\end{array}$ & Clinical (pain, cyanosis) & $\begin{array}{c}\text { Before and after } \\
\text { each HBOT } \\
\text { session }\end{array}$ & Decreased pain & Decreased cyanosis & $\begin{array}{c}\text { HBOT started for } \\
\text { another indication ( } \mathrm{CO} \\
\text { poisoning) }\end{array}$ \\
\hline $\begin{array}{l}\text { William, } \\
\text { 2009, [36] } \\
\text { CRPS }(n=1)\end{array}$ & $\begin{array}{l}\text { Clinical (wound healing, } \\
\text { pain) }\end{array}$ & $\begin{array}{c}\text { Before and after } \\
\text { HBOT }\end{array}$ & $\begin{array}{c}\text { Increased pain, } \\
\text { allodynia, new } \\
\text { neuropathic features }\end{array}$ & Skin color, edema & $\begin{array}{l}\text { (i) HBOT started for } \\
\text { another indication } \\
\text { (wound healing) did } \\
\text { not prevent CRPS } \\
\text { (ii) HBOT was not } \\
\text { subsequentially used as } \\
\text { treatment }\end{array}$ \\
\hline $\begin{array}{l}\text { Katznelson, } \\
\text { 2016, [37] } \\
\text { CRPS }(n=1)\end{array}$ & $\begin{array}{c}\text { Clinical (pain intensity } \\
\text { (VAS), edema, skin } \\
\text { discoloration, ROM); } \\
\text { questionnaires (pain } \\
\text { interference with everyday } \\
\text { functioning (brief pain } \\
\text { inventory (BPI)), mood } \\
\text { and anxiety (hospital } \\
\text { anxiety and depression } \\
\text { scale (HADS))) }\end{array}$ & $\begin{array}{c}\text { Before and after } \\
\text { HBOT, 1- and } \\
\text { 6-month F/U }\end{array}$ & $\begin{array}{l}\text { Decreased pain (VAS } \\
\text { from } 7 \text { to 3.2); marked } \\
\text { BPI decrease (30\% for } \\
\text { general activity), HADS } \\
\text { improvement } \\
\text { (depression from } 9 \text { to } 6 \text {, } \\
\text { anxiety from } 6 \text { to } 4 \text { ) }\end{array}$ & $\begin{array}{l}\text { Improvement of } \\
\text { discoloration, swelling, } \\
\text { ROM; Tinel's sign } \\
\text { disappeared; 6-minute } \\
\text { walk test improvement } \\
\text { (20\%). Decreased } \\
\text { medications to no } \\
\text { medications required }\end{array}$ & \\
\hline $\begin{array}{l}\text { Binkley, 2019, } \\
\text { [38] CRPS } \\
(n=1)\end{array}$ & $\begin{array}{l}\text { Clinical (pain (VAS), } \\
\text { edema, skin discoloration, } \\
\text { ROM, stiffness, tremor; } \\
\text { steroids side effects); } \\
\text { medication doses; quality } \\
\text { of life (QoL) }\end{array}$ & $\begin{array}{c}\text { Before and after } \\
\text { both treatments, } \\
\text { 3- and 6-month } \\
\text { F/U }\end{array}$ & $\begin{array}{l}\text { Improvement of all } \\
\text { clinical findings. } \\
\text { Improved QoL }\end{array}$ & Decreased steroid dose & Mild claustrophobia \\
\hline $\begin{array}{l}\text { van Ophoven, } \\
2004,[39] \text { IC } \\
(n=6)\end{array}$ & $\begin{array}{c}\text { Clinical (pain (VAS), } \\
\text { symptoms severity } \\
\text { (O'Leary-Sant ICSI), } \\
\text { including urgency, } \\
\text { nocturia, frequency); well- } \\
\text { being (PGAF); satisfaction } \\
\text { with HBOT; bladder } \\
\text { biopsy }\end{array}$ & $\begin{array}{l}\text { Before and after } \\
\text { HBOT, F/U: } \\
\text { every } 3 \text { months } \\
\text { for } 15 \text { months } \\
\text { after HBOT }\end{array}$ & $\begin{array}{l}4 \text { responders: decreased } \\
\text { pain (from 2-9.7 to } \\
0.3-3 \text { ), decreased } \\
\text { symptom severity ICSI } \\
\text { (from } 23-35 \text { to 5-16 } \\
\text { after HBOT and 8-24 at } \\
\text { 15-month F/U). } \\
\text { Improved well-being } \\
\text { (PGAF) and ICSI } \\
\text { satisfied } \\
2 \text { nonresponders: no } \\
\text { F/U. Nonsatisfied }\end{array}$ & $\begin{array}{l}\text { (i) Improved ICSI } \\
\text { (ii) Biopsy: } \\
\text { nonulcerative (early) } \\
\text { IC: } 1 \text { responder vs } 1 \\
\text { nonresponder. } \\
\text { Ulcerative (late) IC: } 3 \\
\text { responders vs } 1 \\
\text { nonresponder }\end{array}$ & $\begin{array}{l}\text { (i) No support to the } \\
\text { hypothesis that HBOT } \\
\text { benefits more late-IC } \\
\text { than early-IC } \\
\text { (ii) } 1 \text { mild Eustachian } \\
\text { disfunction }\end{array}$ \\
\hline
\end{tabular}


TABle 7: Continued.

\begin{tabular}{lcccc}
\hline $\begin{array}{l}\text { First author, } \\
\text { year, pain } \\
\text { model } \\
(n \text { patients })\end{array}$ & Outcomes & $\begin{array}{c}\text { Timing of } \\
\text { assessments and } \\
\text { follow-up }\end{array}$ & $\begin{array}{c}\text { Subjective clinical } \\
\text { outcomes }\end{array}$ & $\begin{array}{c}\text { Objective clinical } \\
\text { outcomes }\end{array}$ \\
\hline
\end{tabular}

Primary outcome: efficacy (global response assessment (GRA) van Ophoven, questionnaire). Secondary $(n=21)$ 2006, [40] IC outcomes: pain VAS, urgency (functional bladder capacity), frequency; symptoms severity (O'Leary-Sant ICSI); satisfaction
Before and after HBOT, 3- and 12-month $\mathrm{F} / \mathrm{U}$ responders $(p<0.52)$. At 12-month F/U, 3 patients $(21.4 \%)$ reported treatment response. Decrease of baseline urgency ensity (from $60.2+/$ - decreased (from 25.7 to 15.0 to $49.9+/$ $35.2 \mathrm{~mm}, p<0.05)$, decrease of pain (from $4.3+/-2$ to $3.1+/-2$, $p<0.05)$. Controls: no responders; no parameters improved compared to baseline

\section{7 responders,} significant

Efficacy (ICSI

Tanaka, 2011, [41] IC $(n=11)$
Before and after HBOT, 12month $\mathrm{F} / \mathrm{U}$, variable $\mathrm{F} / \mathrm{U}$ up to 50 months
19.9 points). Controls: no improvements

symp

improvement $>=1)$, clinical (pain (VAS), urgency (VAS)); endoscopic findings improvement in all measures (pain VAS from $7.7 \pm 1.0$ to

$3.4 \pm 2.5$; urgency VAS

from $6.6 \pm 0.9$ to $4.3 \pm 2.4)$; sustained at $\mathrm{F} / \mathrm{U}$

5 responders, 1 nonresponder, 3 withdrew but

Primary outcome: efficacy

Wenzler, 2017, [42] IC $(n=9)$

(GRA). Secondary: clinical Before HBOT, symptoms (voiding diary, $\mathrm{F} / \mathrm{U}$ after $\mathrm{HBO}$ :

ICSI and ICPI 2 weeks, months questionnaires, VAS); $\quad 3,6,12$ cystoscopic appearance

\section{considered}

nonresponder.

Responders: GRA

improved; VAS (1.5

points) improvement; voiding nonsignificant (i) Improved ICSI (from $26.7 \pm 7.0$ to $18.7 \pm 7.4(p<0.05))$

(ii) Biopsy: 3 of the 4 nonresponders had nonulcerative IC

$$
\begin{aligned}
& \text { regarding the peak } \\
& \text { amelioration of }
\end{aligned}
$$
symptoms compared to placebo
Conclusion: HBOT provides sustained decrease of IC symptoms with a discordant profile
1 mild Eustachian disfunction, 3 mild exudative otitis media
Primary endpoint: warm sensory threshold.

Secondary: heat pain

Pritchard, 2001, [43] RIBP $(n=34)$ threshold, cool sensation threshold, routine neurophysiological tests, pain (McGill pain questionnaire), and QoL (MOS SF-36 questionnaire)

\begin{tabular}{lccc}
\hline Videtic, 1999, & Clinical (pain), medication & Before and after & Marked pain \\
[44] sacral & HBOT, 12- & improvement (from \\
plexopathy & doses & month F/U & severe to none) \\
$(n=1)$ & & m
\end{tabular}

Before HBOT, No significant 1-week F/U, 12- difference between month $\mathrm{F} / \mathrm{U}$ groups (i) Improved ICSI, ICPI (1.5 points)

(ii) Biopsy: 2 out of 3 ulcerative IC improved (i) Nonulcerative IC (1 pt): marked improvement/ resolution; ulcerative IC (4 pts): mild to moderate improvement

(ii) No adverse events

(i) Placebo protocol is HBOT (therapeutic itself), not a real placebo. difference between groups. Intervention: nonsignificant improvement of warm sensory threshold (ii) Anecdotal evidence of improvement in longstanding arm lymphedema is an unexpected outcome of this study

HBOT started for another indication (ORN) 
TABle 7: Continued.

\begin{tabular}{|c|c|c|c|c|}
\hline \multirow{2}{*}{$\begin{array}{l}\text { First author, } \\
\text { year, pain } \\
\text { model } \\
\text { ( } n \text { patients })\end{array}$} & \multirow[b]{2}{*}{ Outcomes } & \multirow{2}{*}{$\begin{array}{l}\text { Timing of } \\
\text { assessments and } \\
\text { follow-up }\end{array}$} & \multicolumn{2}{|c|}{ Results } \\
\hline & & & $\begin{array}{l}\text { Subjective clinical } \\
\text { outcomes }\end{array}$ & $\begin{array}{c}\text { Objective clinical } \\
\text { outcomes }\end{array}$ \\
\hline $\begin{array}{l}\text { Stowe, } 2020 \text {, } \\
{[45] \text { RIBP }} \\
(n=1)\end{array}$ & $\begin{array}{c}\text { Clinical (pain, ROM, } \\
\text { neuroexam (sensory, } \\
\text { motor)); imaging (brachial } \\
\text { plexus MRI) }\end{array}$ & $\begin{array}{l}\text { Before HBOT, } \\
\text { F/U at } 2,6 \text {, and } \\
13 \text { months }\end{array}$ & $\begin{array}{l}\text { Pain: from sever to } \\
\text { none }\end{array}$ & $\begin{array}{c}\text { (i) ROM: from } \\
\text { decreased to full } \\
\text { (ii) Imaging: } \\
\text { significantly decreased } \\
\text { abnormal } \\
\text { enhancement }\end{array}$ \\
\hline
\end{tabular}

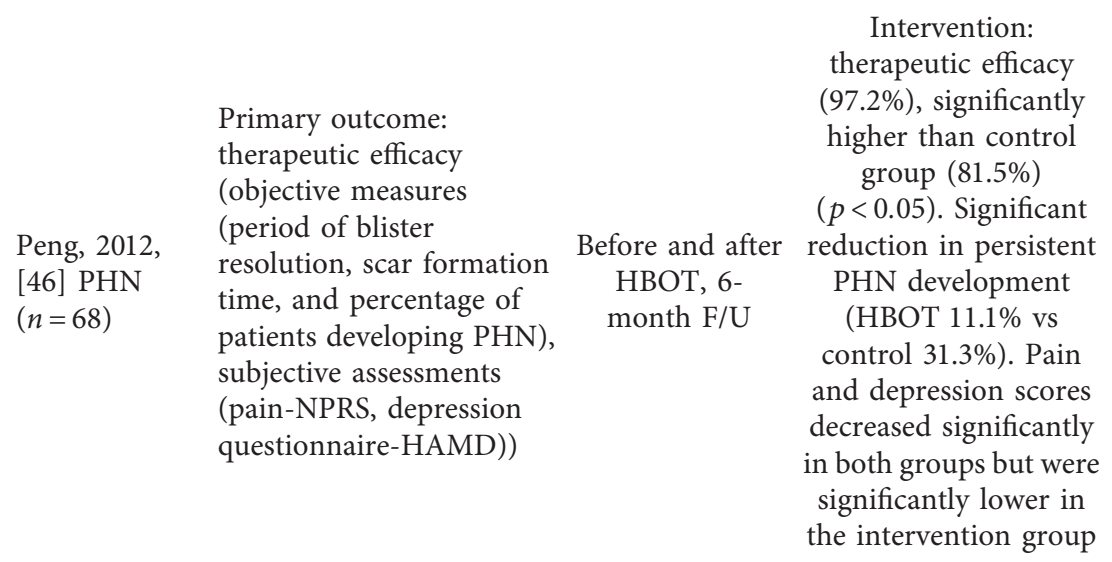

Intervention:

significant reduction in scar formation time (HBOT 11.1 days \pm 4 vs control 14 days \pm 4.3 )
Benefit could be related to a longer HBOT

(120 min) compared to other literature

(90 min) and to an early diagnosis and treatment

(i) Study outcomes were measured when by natural history one would expect the infection to have resolved (5 weeks)

(ii) Small differences in pain after treatment could be not clinically significant

(ii) Although this is a positive study for

HBOT in PHN, further studies are needed with chronic PHN (>3

months from onset) and longer follow-up periods

(i) A placebo effect was shown in the study (carbamazepine doses and VAS were

decreased in the sham group, although the

decrease was to a lesser degree than the treatment group)

(ii) This study also implicates other cranial neuralgias as possible indications for HBOT

$n=$ number; HBOT = hyperbaric oxygen therapy; $\mathrm{CRPS}=$ chronic regional pain syndrome; $\mathrm{IC}=$ interstitial cystitis; RIBP= radiation-induced brachial plexopathy; $\mathrm{PHN}=$ postherpetic neuralgia; $\mathrm{TN}=$ trigeminal neuralgia; $\mathrm{VAS}=$ visual analogue scale; $\mathrm{ROM}=$ range of motion; $\mathrm{QoL}=$ quality of life, ICSI = interstitial cystitis symptom index; ICPI = interstitial cystitis problem index; PGAF = patient global assessment form; MOS SF-36 = medical outcomes study, 36-Item Short Form Health Survey; MRI = magnetic resonance imaging; NPRS = numeric pain rating scale; HAMD= Hamilton depression rating scale; $\mathrm{F} / \mathrm{U}=$ follow-up; $\mathrm{ORN}=$ osteoradio necrosis.

extension), and edema (wrist circumference) at baseline, at the end of the 15 HBOT sessions, and at 45-day follow-up. The HBOT group reported significantly lower pain scores, improved range of motion, and decreased edema, both at the end of HBOT and at the follow-up sessions, while the control group did not have any improvement. The authors concluded that HBOT was effective in decreasing pain and swelling and increasing wrist range of motion in patients with CRPS. Given that the sham control was also exposed to higher pressure (breathing air at 2.4 ATA), this study implicates the therapeutic benefits of hyperoxia rather than just increased atmospheric pressure environment, although it should be noted that even the control group experienced higher levels of oxygenation at 2.4 ATA.
3.2.4. Role of HBOT in Acute and Chronic CRPS. Another possible mechanism for HBOT in CRPS is in preventing progression of the disease from the early acute and dystrophic stages to the irreversible/atrophic stage that is characterized by stiffness and flexion contractures. A critique of the previous RCT [33] was that the population studied were young and otherwise healthy soldiers receiving HBOT within 1.5 months of the original injury. It was postulated that because HBOT stimulates the activity of osteoblasts and decreases formation of fibrosis [54], it interrupts the basic vicious cycle of CRPS pathophysiology.

Williams et al. [36] described a case report of a 48-yearold diabetic man who developed complications after elective subtalar arthrodesis for chronic ankle instability. Following 
two irrigations and debridement for infection, the patient received 19 sessions ( $90 \mathrm{~min}$ at $2.2 \mathrm{ATA}$ ) of HBOT for wound healing enhancement, starting 3 weeks after the first surgery. One month after HBOT the wound was completely healed, but the patient started to develop neuropathic pain and other symptoms pertinent to CRPS. The authors concluded that HBOT, even if initiated early after a traumatic extremity injury, did not confer any protection against the possibility to developing CRPS.

Two case reports described potential benefits of HBOT in patients with chronic CRPS [37, 38]. A 41-year-old male with a 1-year history of left-foot CRPS following ankle fracture demonstrated less pain, decreased swelling, less allodynia, improvement in skin color, and a range of motion of the lower limb after 3 weeks of HBOT [37]. Furthermore, his mood and walking ability as well as interactions with other people and enjoyment of life markedly improved. Another case report [38] described a 50-year-old female with an 8-year complicated history of CRPS following the left fifth proximal phalanx fracture, in which multiple conventional and nonconventional therapies failed. The disease was partially controlled with a high dose of prednisone $(85 \mathrm{mg} /$ day). After 40 HBOT sessions, 90 minutes each at 2.4 ATA, the prednisone dose was reduced to $9 \mathrm{mg} /$ day, with marked improvement in symptoms. Five months after the HBOT sessions, the patient had a mild flare of symptoms and received a second HBOT course of 33 sessions, 90 minutes each at 2.0 ATA, again with marked improvement, and further decrease in prednisone to $5 \mathrm{mg}$ /day. The patients also experienced significant reduction of steroid related complications including diabetes, hypertension, dyslipidemia, insomnia, skin integrity, infections, and bruising. Even though these case reports are promising, it is paramount to acquire more robust evidence to advocate for $\mathrm{HBOT}$ as a standard treatment in patients with acute and chronic CRPS.

3.2.5. Cerebral Targets for HBOT in CRPS. A fourth potential mechanism for HBOT benefit is through central or cerebral effects. A study by Barad et al. [55] discovered decreased gray matter changes in the limbic system (posterior mid-cingulate cortex, bilateral pregenual anterior cingulate cortex, and orbitofrontal cortex) and left posterior insula and increased gray matter in the dorsal putamen and hypothalamus that is involved in the processing of pain in patients with CRPS. Duration of illness and increased pain intensity were correlated with gray matter atrophy in the dorsolateral prefrontal cortex and gray matter hypertrophy in the hippocampus and amygdala. While brain changes have not been demonstrated in HBOT with CRPS patients, preliminary data from the fibromyalgia population demonstrate a rectification of imbalanced brain activity after treatments with HBOT $[32,56]$.

3.3. HBOT in Chronic Primary Bladder Pain Syndrome. The reports of HBOT in chronic primary bladder pain syndrome are reflected in Tables 6 and 7.

Also known as interstitial cystitis, bladder pain syndrome (BPS) is characterized by chronic pelvic pain or discomfort, associated with at least one urinary symptom, such as persistent urge to void, increased frequency, and nocturia $[57,58]$. Under the ICD-11 classification BPS is considered as a chronic primary pain disorder [5]. Ophoven et al. $[39,40]$ sought to determine the feasibility and efficacy of HBOT in BPS based on observations of decreased pelvic pain in patients undergoing HBOT for radiation cystitis. Following a feasibility study [39], van Ophoven et al. conducted a randomized, sham controlled, double-blind trial [40] whereby 14 patients (experimental group) received 30 HBOT treatments at 2.4 ATA for 90 minutes and 6 patients (control group) received a sham treatment breathing room air at 1.3-1.4 ATA. Pain intensity measured by visual analogue scores (VAS) decreased significantly in the experimental group compared to the control group at 3-month follow-up. A prospective cohort study by Tanaka et al. [41] evaluated 11 patients with BPS symptoms who received 10-20 HBOT treatments for 60 minutes each at 2.0 ATA. Seven "responders" demonstrated a significant improvement in pain scores at 12-month follow-up. A pilot study by Wenzler et al. [42] evaluated 9 patients with interstitial cystitis receiving $30 \mathrm{HBOT}$ sessions of 90 minutes at 2.2 ATA. Five "responders" had considerable reduction in VAS at the 12-month follow-up. Histological findings from patients with BPS demonstrated decreased microvascular density in the suburothelial plexus which was indicative of reduced edema and decreased vascular congestion. Consequently, HBOT-mediated neoangiogenesis and increased tissue oxygenation may serve as two proposed mechanisms for improved pain relief in patients with BPS.

3.4. HBOT in Chronic Secondary Neuropathic Pain. Among the chronic secondary pain syndromes, there is a growing body of evidence in support of HBOT's efficacy in neuropathic (peripheral) pain syndromes such as radiationand chemotherapy-induced plexus neuropathies, postherpetic neuralgia (PHN), and trigeminal neuralgia (TN). HBOT has been also effective in managing secondary neuropathic conditions such as HIV-associated neuropathy [59], peripheral nerve injury $[60,61]$, and optic neuropathy [62-67].

3.4.1. Radiation-Induced Plexus Neuropathies. Efficacy of HBOT in radiotherapy induced brachial and sacral plexus neuropathy has been evaluated in three clinical studies (Tables 6 and 7).

Pritchard et al. [43] reported the use of HBOT as an adjunctive therapy for radiation-induced brachial plexopathy (RIBP), an intractable neuropathic pain resulting in severe motor dysfunction [68]. 34 patients with RIBP were randomized to either experimental $\left(100 \% \mathrm{O}_{2}\right.$ at $\left.2.4 \mathrm{ATA}\right)$ or control $\left(41 \% \mathrm{O}_{2}\right.$ at $\left.2.4 \mathrm{ATA}\right)$ groups for 30 sessions of 90 minutes. Clinical and neurologic assessments including warm sensory threshold (measuring the function of small sensory fibers) and pain and quality of life questionnaires were conducted after the end of the HBOT treatment period and at 1- and 2-year follow-up. No differences in clinical outcomes either between or within the groups were found 
for up to 1-year follow-up. However, 2 patients in the HBOT group exhibited normalization of the warm sensory threshold, and 2 other patients experienced normalization of chronic arm lymphedema. While the authors concluded that "there is currently no basis for recommending HBOT as a proven treatment for RIBP," it should be noted that statistical analysis was performed for just a single primary endpoint, "warm sensory threshold," and no formal analysis was done for secondary endpoints, including pain. Additionally, while there was no "within-group" benefit, it should be noted that the control group was breathing $41 \% \mathrm{O}_{2}$ at 2.4 ATA, which corresponds to approximately $100 \%$ oxygen at 1 ATA. Indeed, breathing $100 \%$ oxygen at sea level is considered a therapy by itself, since the increase in blood oxygen content could exert beneficial effects [69].

A case report by Videtic and Venkatesan [44] noted the beneficial effects of HBOT on sacral plexopathy causing severe pelvic pain in a 55-year-old woman. While the HBOT indication was for sacral osteoradionecrosis due to radiotherapy for bladder leiomyosarcoma, severe pain was a main symptom. Her pain was not responding to opioid analgesics, anti-inflammatories, dexamethasone, and amitriptyline. The patient received 30 sessions of $\mathrm{HBOT}$ at 2.5 ATA with a gradual but constant decrease on opioid requirement. 12month follow-up consultation revealed no pain and no pain medications apart from minimal dose of amitriptyline. Another case report [45] described a brachial plexopathy in a 45-year-old man who underwent radiotherapy for neck carcinoma. He developed severe left shoulder/arm pain and decreased range of motion (ROM) after 15 months and RIBP diagnosis was confirmed by brachial plexus magnetic resonance imaging (MRI). He received dexamethasone for 2 weeks and underwent 30 HBOT sessions at 2.4 ATA, 120 minutes each. At 2-month and 13-month follow-up the patient regained full ROM in his left arm and reported no pain. These clinical findings were corroborated by a significant decrease of abnormal enhancement on follow-up MRI at 6 months. The authors hypothesized that the potential benefit could be related to longer HBOT sessions (120 minutes) as well as an early diagnosis and treatment. The results of these case studies suggest a potential benefit of HBOT for radiation-induced neuropathic pain and merit further investigations.

3.4.2. Postherpetic Neuralgia. Postherpetic neuralgia (PHN) consists of a persistent irritation and intermittent neuropathic pain, usually associated with allodynia and itching [70], that persist after a primary herpes zoster infection. Peng et al. [46] randomized 68 patients who developed acute herpes zoster infection within 2 weeks to either intervention group (receiving HBOT 30 sessions, twice daily, 80 minutes each at 2.2 ATA, in addition to medical therapy) or control group, receiving optimal medical therapy (antiviral [acyclovir], nerve nutritive [mecobalamin], pain relief [tramadol], and antidepressant [nortriptyline]). Effectiveness of HBOT was assessed by objective measures including period of blister resolution, scar formation time and percentage of patients developing $\mathrm{PHN}$, and subjective assessments with questionnaires reflecting pain and depression. Based on these assessments, all patients were categorized into three different "therapeutic efficacy" classes, namely, healed, improved, or ineffective. Overall, the calculated therapeutic efficacy in the HBOT group was significantly higher than in the control group (97 vs $81 \%$ ). The HBOT group exhibited a significant reduction in persistent $\mathrm{PHN}$ development when compared to control group (11 vs $31 \%$ ) and in scar formation time (11 vs 14 days). Pain and depression scores decreased in both groups; however, they were significantly lower in the HBOT group compared to controls. The authors concluded that "the combination of HBOT and conventional pharmacological therapy was more effective than pharmacological treatment alone." A critical appraisal [71] highlighted that the study outcomes were measured when by natural history one would expect the infection to have resolved anyway (within 5 weeks period) and that the numerical differences in pain scores between the two groups were lacking clinical significance. It is clear that further studies with long-term follow-up are needed to determine the efficacy of HBOT in patients with chronic PHN.

3.4.3. Trigeminal Neuralgia. Trigeminal neuralgia (TN) is defined as a neuropathic facial pain condition, characterized by unilateral paroxysmal pain, evoked by trigger factors $[72,73]$. Under the new ICD-11, TN overlaps two different categories and is considered an example of "multiple parenting," since it can be classified as both a chronic primary pain (subcategory of chronic primary headache/orofacial pain) and a chronic secondary peripheral neuropathic pain [4]. Multiple clinical studies of HBOT have been conducted in patients with chronic migraine and cluster headaches [74]; however, they are beyond the scope of this review. Nonetheless, TN plays a special role in both mechanistic rationale and clinical efficacy of $\mathrm{HBOT}$ in patients with neuropathic pain.

Many animal models for TN involve constriction, compression, or ligation of neural structures $[18,75,76]$ to produce mechanical or thermal allodynia. These models are either identical or parallel to those used in elucidating the mechanism by which HBOT exerts antinociceptive effects in animals as discussed earlier in the "animal models" section (Table 5). Gu et al. [18] evaluated the effect of HBOT following chronic constriction injury of the sciatic nerve in rats and also conducted a trial in humans with idiopathic TN. In the animal model, they demonstrated that repetitive HBOT produced a rapid, dose-dependent, and long-lasting inhibition of thermal hyperalgesia and mechanical allodynia. In the clinical study, 42 patients with $\mathrm{TN}$, concurrently treated with carbamazepine, were randomized to a treatment group (22 patients) receiving 10 sessions of HBOT for 70 minutes at 1.8 ATA or to a sham group (20 patients) receiving the same treatment in a hyperbaric chamber breathing room air at atmospheric pressure. Effectiveness of HBOT was assessed by carbamazepine dose reduction and VAS score changes at the 6-month follow-up. After 10 HBOT sessions, the treatment group had a significant decrease in required carbamazepine dose that lasted up to 90 days. Carbamazepine dose was also significantly lower when 
compared to the sham group for up to 60 days after HBOT. This was associated with significant reduction in VAS up to 6 months after HBOT.

\section{Conclusions}

There is a growing body of evidence suggesting the potential benefits and therapeutic impact of HBOT in different chronic neuropathic pain conditions. The current literature confirms a wide heterogeneity in the HBOT treatment modalities in patients with different chronic neuropathic pain presentations suggesting that appropriate dose-response curve specifics should be considered for each condition. HBOT has been shown to reduce pain scores and improve pain-related symptoms and quality of life. Future research should focus on the identification of a subset of patients with chronic pain who can benefit from HBOT.

\section{Data Availability}

Data are available in Supplementary Materials and are anyway available upon request to the corresponding author.

\section{Conflicts of Interest}

The authors declare that they have no conflicts of interest.

\section{Supplementary Materials}

The supplementary materials include the Medline search strategy. . (Supplementary Materials)

\section{References}

[1] H. Breivik, B. Collett, V. Ventafridda, R. Cohen, and D. Gallacher, "Survey of chronic pain in Europe: prevalence, impact on daily life, and treatment," European Journal of Pain, vol. 10 , no. 4 , p. $287,2006$.

[2] D. E. Moulin, A. J. Clark, M. Speechley, and P. K. MorleyForster, "Chronic pain in Canada-prevalence, treatment, impact and the role of opioid analgesia," Pain Research and Management, vol. 7, no. 4, pp. 179-184, 2002.

[3] J. Scholz, N. B. Finnerup, N. Attal et al., "The IASP classification of chronic pain for ICD-11: chronic neuropathic pain," Pain, vol. 160, no. 1, pp. 53-59, 2019.

[4] R. D. Treede, W. Rief, A. Barke et al., "Chronic pain as a symptom or a disease: the IASP classification of chronic pain for the international classification of diseases (ICD-11)," Pain, vol. 160, no. 1, pp. 19-27, 2019.

[5] M. Nicholas, J. W. S. Vlaeyen, W. Rief et al., "The IASP classification of chronic pain for ICD-11: chronic primary pain," Pain, vol. 160, no. 1, pp. 28-37, 2019.

[6] D. Bates, B. C. Schultheis, M. C. Hanes et al., "A comprehensive algorithm for management of neuropathic pain," Pain Medicine, vol. 20, no. Supplement_1, pp. S2-s12, 2019.

[7] S. R. Thom, "Analytic reviews: hyperbaric oxygen therapy," Journal of Intensive Care Medicine, vol. 4, no. 2, pp. 58-74, 1989.

[8] S. R. Thom, "Hyperbaric oxygen: its mechanisms and efficacy," Plastic and Reconstructive Surgery, vol. 127, pp. 131S141S, 2011.
[9] R. E. Moon, Hyperbaric Oxygen Therapy Indications, UHMS, North Palm Beach, FL, USA, 14th edition, 2019.

[10] K. K. Jain, "Indications, contraindications, and complications of HBO therapy," in Textbook of Hyperbaric Medicine, pp. 79-84, Springer, Berlin, Germany, 2017

[11] T. J. Coderre and G. J. Bennett, "A hypothesis for the cause of complex regional pain syndrome-type I (reflex sympathetic dystrophy): pain due to deep-tissue microvascular pathology," Pain Medicine, vol. 11, no. 8, pp. 1224-1238, 2010.

[12] G. A. Bellingham, R. S. Smith, P. Morley-Forster, and J. M. Murkin, "Use of near infrared spectroscopy to detect impaired tissue oxygen saturation in patients with complex regional pain syndrome type 1," Canadian Journal of Anesthesia/Journal Canadien D'anesthésie, vol. 61, no. 6, pp. 563-570, 2014.

[13] G. Nylander, D. Lewis, H. Nordström, and J. Larsson, "Reduction of postischemic edema with hyperbaric oxygen," Plastic and Reconstructive Surgery, vol. 76, no. 4, pp. 596-601, 1985.

[14] A. C. Tricco, E. Lillie, W. Zarin et al., "PRISMA extension for scoping reviews (PRISMA-ScR): checklist and explanation," Annals of Internal Medicine, vol. 169, no. 7, pp. 467-473, 2018.

[15] G. J. Bennett and Y.-K. Xie, "A peripheral mononeuropathy in rat that produces disorders of pain sensation like those seen in man," Pain, vol. 33, no. 1, pp. 87-107, 1988.

[16] P. Medeiros, I. R. Dos Santos, I. M. Júnior et al., “An adapted chronic constriction injury of the sciatic nerve produces sensory, affective, and cognitive impairments: a peripheral mononeuropathy model for the study of comorbid neuropsychiatric disorders associated with neuropathic pain in rats," Pain Medicine, vol. 22, no. 2, pp. 338-351, 2021.

[17] F. Li, L. Fang, S. Huang et al., "Hyperbaric oxygenation therapy alleviates chronic constrictive injury-induced neuropathic pain and reduces tumor necrosis factor-alpha production," Anesthesia \& Analgesia, vol. 113, no. 3, pp. 626-633, 2011.

[18] N. Gu, J.-Y. Niu, W.-T. Liu et al., "Hyperbaric oxygen therapy attenuates neuropathic hyperalgesia in rats and idiopathic trigeminal neuralgia in patients," European Journal of Pain, vol. 16, no. 8, pp. 1094-1105, 2012.

[19] C. D. Thompson, M. L. Uhelski, J. R. Wilson, and P. N. Fuchs, "Hyperbaric oxygen treatment decreases pain in two nerve injury models," Neuroscience Research, vol. 66, no. 3, pp. 279-283, 2010.

[20] C. R. Gibbons, S. Liu, Y. Zhang et al., "Involvement of brain opioid receptors in the anti-allodynic effect of hyperbaric oxygen in rats with sciatic nerve crush-induced neuropathic pain," Brain Research, vol. 1537, pp. 111-116, 2013.

[21] B. S. Zhao, X. R. Song, P. Y. Hu et al., "Hyperbaric oxygen treatment at various stages following chronic constriction injury produces different antinociceptive effects via regulation of P2X4R expression and apoptosis," PLoS One, vol. 10, no. 3, Article ID e0120122, 2015.

[22] B.-S. Zhao, L.-X. Meng, Y.-Y. Ding, and Y.-Y. Cao, "Hyperbaric oxygen treatment produces an antinociceptive response phase and inhibits astrocyte activation and inflammatory response in a rat model of neuropathic pain," Journal of Molecular Neuroscience, vol. 53, no. 2, pp. 251-261, 2014.

[23] G. Han, L. Li, and L.-X. Meng, "Effects of hyperbaric oxygen on pain-related behaviours and nitric oxide synthase expression in a rat model of neuropathic pain," Pain Research and Management, vol. 18, no. 3, pp. 137-141, 2013. 
[24] Y. Ding, P. Yao, T. Hong et al., "Early hyperbaric oxygen effects on neuropathic pain and nitric oxide synthase isoforms in CCI rats," Oncotarget, vol. 9, no. 7, pp. 7513-7521, 2018.

[25] H. Fu, F. Li, S. Thomas, and Z. Yang, "Hyperbaric oxygenation alleviates chronic constriction injury (CCI)-induced neuropathic pain and inhibits GABAergic neuron apoptosis in the spinal cord," Scandinavian Journal of Pain, vol. 17, no. 1, pp. 330-338, 2017.

[26] A. L. Brewer, D. Y. Shirachi, R. M. Quock, and R. M. Craft, "Effect of hyperbaric oxygen on chemotherapy-induced neuropathy in male and female rats," Behavioural Pharmacology, vol. 31, no. 1, pp. 61-72, 2020.

[27] E. Khademi, V. Pirhajati Mahabadi, H. Ahmadvand, E. Akbari, and A. R. Khalatbary, "Anti-inflammatory and anti-apoptotic effects of hyperbaric oxygen preconditioning in a rat model of cisplatin-induced peripheral neuropathy," Iranian Journal of Basic Medical Sciences, vol. 23, no. 3, pp. 321-328, 2020.

[28] H. D. Wilson, J. R. Wilson, and P. N. Fuchs, "Hyperbaric oxygen treatment decreases inflammation and mechanical hypersensitivity in an animal model of inflammatory pain," Brain Research, vol. 1098, no. 1, pp. 126-128, 2006.

[29] L. M. Zelinski, Y. Ohgami, E. Chung, D. Y. Shirachi, and R. M. Quock, "A prolonged nitric oxide-dependent, opioidmediated antinociceptive effect of hyperbaric oxygen in mice," The Journal of Pain, vol. 10, no. 2, pp. 167-172, 2009.

[30] S. R. Thom, V. Bhopale, D. Fisher, Y. Manevich, P. L. Huang, and D. G. Buerk, "Stimulation of nitric oxide synthase in cerebral cortex due to elevated partial pressures of oxygen: an oxidative stress response," Journal of Neurobiology, vol. 51, no. 2, pp. 85-100, 2002.

[31] Y. Ohgami, C. C. Zylstra, L. P. Quock, E. Chung, D. Y. Shirachi, and R. M. Quock, "Nitric oxide in hyperbaric oxygen-induced acute antinociception in mice," NeuroReport, vol. 20, no. 15, pp. 1325-1329, 2009.

[32] S. Efrati, H. Golan, Y. Bechor et al., "Hyperbaric oxygen therapy can diminish fibromyalgia syndrome-prospective clinical trial," PLoS One, vol. 10, no. 5, Article ID e0127012, 2015.

[33] M. Kiralp, Ș. Yildiz, D. Vural, I. Keskin, H. Ay, and H. Dursun, "Effectiveness of hyperbaric oxygen therapy in the treatment of complex regional pain syndrome," Journal of International Medical Research, vol. 32, no. 3, pp. 258-262, 2004.

[34] D. Salvemini, J. W. Little, T. Doyle, and W. L. Neumann, "Roles of reactive oxygen and nitrogen species in pain," Free Radical Biology and Medicine, vol. 51, no. 5, pp. 951-966, 2011.

[35] G. Peach, "Hyperbaric oxygen and the reflex sympathetic dystrophy syndrome: a case report," Undersea \& Hyperbaric Medicine: Journal of the Undersea and Hyperbaric Medical Society, vol. 22, no. 4, pp. 407-408, 1995.

[36] S. T. Williams, A. Davies, and P. Bryson, "Chronic regional pain syndrome after subtalar arthrodesis is not prevented by early hyperbaric oxygen," Pain physician, vol. 12, no. 5, pp. E335-E339, 2009.

[37] R. Katznelson, S. C. Segal, and H. Clarke, "Successful treatment of lower limb complex regional pain syndrome following three weeks of hyperbaric oxygen therapy," Pain Research and Management, vol. 2016, Article ID 3458371, 4 pages, 2016.

[38] K. Binkley and R. Katznelson, "Successful treatment of long standing complex regional pain syndrome with hyperbaric oxygen therapy," Journal of Neuroimmune Pharmacology, vol. 15, no. 1, pp. 1-6, 2019.
[39] A. Van Ophoven, G. Rossbach, F. Oberpenning, and L. Hertle, "Hyperbaric oxygen for the treatment of interstitial cystitis: long-term results of a prospective pilot study," European Urology, vol. 46, no. 1, pp. 108-113, 2004.

[40] A. Van Ophoven, G. Rossbach, F. Pajonk, and L. Hertle, "Safety and efficacy of hyperbaric oxygen therapy for the treatment of interstitial cystitis: a randomized, sham controlled, double-blind trial," Journal of Urology, vol. 176, no. 4, pp. 1442-1446, 2006.

[41] T. Tanaka, Y. Nitta, K. Morimoto et al., "Hyperbaric oxygen therapy for painful bladder syndrome/interstitial cystitis resistant to conventional treatments: long-term results of a case series in Japan," BMC Urology, vol. 11, p. 11, 2011.

[42] D. L. Wenzler, F. Gulli, M. Cooney, M. B. Chancellor, J. Gilleran, and K. M. Peters, "Treatment of ulcerative compared to non-ulcerative interstitial cystitis with hyperbaric oxygen: a pilot study," Therapeutic Advances in Urology, vol. 9, no. 12, pp. 263-270, 2017.

[43] J. Pritchard, P. Anand, J. Broome et al., "Double-blind randomized phase II study of hyperbaric oxygen in patients with radiation-induced brachial plexopathy," Radiotherapy and Oncology, vol. 58, no. 3, pp. 279-286, 2001.

[44] G. M. Videtic and V. M. Venkatesan, "Hyperbaric oxygen corrects sacral plexopathy due to osteoradionecrosis appearing 15 years after pelvic irradiation," Clinical Oncology, vol. 11, no. 3, pp. 198-199, 1999.

[45] H. B. Stowe, B. T. Mullins, and B. S. Chera, "Hyperbaric oxygen therapy for radiation-induced brachial plexopathy, a case report and literature review," Reports of Practical Oncology \& Radiotherapy, vol. 25, no. 1, pp. 23-27, 2020.

[46] Z. Peng, S. Wang, X. Huang, and P. Xiao, "Effect of hyperbaric oxygen therapy on patients with herpes zoster," Undersea and Hyperbaric Medical Society, vol. 39, no. 6, pp. 1083-1087, 2012.

[47] R. N. Harden, A. L. Oaklander, A. W. Burton et al., "Complex regional pain syndrome: practical diagnostic and treatment guidelines, 4th edition," Pain Medicine, vol. 14, no. 2, pp. 180-229, 2013.

[48] J. Eldufani, N. Elahmer, and G. Blaise, "A medical mystery of complex regional pain syndrome," Heliyon, vol. 6, no. 2, Article ID e03329, 2020.

[49] S. Bruehl, "Complex regional pain syndrome," BMJ, vol. 351, 2015.

[50] A. Larsson, J. Uusijärvi, S. Eksborg, and P. Lindholm, “Tissue oxygenation measured with near-infrared spectroscopy during normobaric and hyperbaric oxygen breathing in healthy subjects," European Journal of Applied Physiology, vol. 109, no. 4, pp. 757-761, 2010.

[51] D. Mathieu, R. Favory, F. Collet, J. C. Linke, and F. Wattel, "Physiologic effects of hyperbaric oxygen on hemodynamics and microcirculation," in Handbook on Hyperbaric Medicine, pp. 75-101, Springer-Verlag, Berlin, Germany, 2006.

[52] M. Heyboer, S. M. Wojcik, G. Smith, and W. Santiago, "Effect of hyperbaric oxygen therapy on blood pressure in patients undergoing treatment," Undersea and Hyperbaric Medicine, vol. 44, no. 2, pp. 93-99, 2017.

[53] T. Nakada, H. Koike, T. Katayama, H. Watanabe, and Y. Yamori, "Increased adrenal epinephrine and norepinephrine in spontaneously hypertensive rats treated with hyperbaric oxygen," Hinyokika Kiyo. Acta Urologica Japonica, vol. 30, no. 10, pp. 1357-1366, 1984.

[54] X. Ye, J. Zhang, R. Lu, and G. Zhou, "HBO: a possible supplementary therapy for oral potentially malignant disorders," Medical Hypotheses, vol. 83, no. 2, pp. 131-136, 2014. 
[55] M. J. Barad, T. Ueno, J. Younger, N. Chatterjee, and S. Mackey, "Complex regional pain syndrome is associated with structural abnormalities in pain-related regions of the human brain," The Journal of Pain, vol. 15, no. 2, pp. 197-203, 2014.

[56] A. Hadanny, Y. Bechor, M. Catalogna et al., "Hyperbaric oxygen therapy can induce neuroplasticity and significant clinical improvement in patients suffering from fibromyalgia with a history of childhood sexual abuse-randomized controlled trial," Frontiers in Psychology, vol. 9, 2018.

[57] J. Neuhaus and T. Schwalenberg, "Intravesical treatments of bladder pain syndrome/interstitial cystitis," Nature Reviews Urology, vol. 9, no. 12, pp. 707-720, 2012.

[58] J. P. Van de Merwe, J. Nordling, P. Bouchelouche et al., "Diagnostic criteria, classification, and nomenclature for painful bladder syndrome/interstitial cystitis: an ESSIC proposal," European Urology, vol. 53, no. 1, pp. 60-67, 2008.

[59] W. C. Jordan, "The effectiveness of intermittent hyperbaric oxygen in relieving drug-induced HIV-associated neuropathy," Journal of the National Medical Association, vol. 90, no. 6, pp. 355-358, 1998.

[60] D. W. Zhao, "[Therapeutic effect of hyperbaric oxygen on recovery of surgically repaired peripheral nerve injury]," Zhonghua Wai Ke Za Zhi, vol. 29, no. 2, pp. 118-120, 1991.

[61] J. Nazario and D. P. Kuffler, "Hyperbaric oxygen therapy and promoting neurological recovery following nerve trauma," Undersea and Hyperbaric Medical Society, vol. 38, no. 5, pp. 345-366, 2011.

[62] H. M. Allashem, D. G. Sward, K. Sethuraman, and M. K. Matthews, "Hyperbaric oxygen therapy for perioperative posterior ischemic optic neuropathy: a case report," Undersea and Hyperbaric Medical Society, vol. 46, no. 5, pp. 701-707, 2019.

[63] Y.-H. Hsieh, C.-M. Liang, M.-C. Tai, and Y.-J. Chen, "Benefit of hyperbaric oxygen therapy treatment in direct traumatic optic neuropathy: case report," Undersea and Hyperbaric Medicine, vol. 45, no. 4, pp. 463-471, 2018.

[64] C. Q. Li, S. Gerson, and B. Snyder, "Case report: hyperbaric oxygen and MRI findings in radiation-induced optic neuropathy," Undersea and Hyperbaric Medical Society, vol. 41, no. 1, pp. 59-63, 2014.

[65] S. D. Register, M. E. Aaron, and H. B. Gelly, "Hyperbaric oxygen therapy and optic neuritis: case report and literature review," Undersea and Hyperbaric Medical Society, vol. 38, no. 6, pp. 557-559, 2011.

[66] A. Malik and K. Golnik, "Hyperbaric oxygen therapy in the treatment of radiation optic neuropathy," Journal of NeuroOphthalmology, vol. 32, no. 2, pp. 128-131, 2012.

[67] R. L. Levy and N. R. Miller, "Hyperbaric oxygen therapy for radiation-induced optic neuropathy," Annals of the Academy of Medicine, vol. 35, no. 3, pp. 151-157, 2006.

[68] J. Gosk, R. Rutowski, P. Reichert, and J. Rabczyński, "Radiation-induced brachial plexus neuropathy-aetiopathogenesis, risk factors, differential diagnostics, symptoms and treatment," Folia Neuropathologica, vol. 45, no. 1, pp. 26-30, 2007.

[69] N. C. Lansdorp and R. A. Van Hulst, "Double-blind trials in hyperbaric medicine: a narrative review on past experiences and considerations in designing sham hyperbaric treatment," Clinical Trials, vol. 15, no. 5, pp. 462-476, 2018.

[70] R. Baron and G. Wasner, "Prevention and treatment of postherpetic neuralgia," The Lancet, vol. 367, no. 9506, pp. 186-188, 2006.

[71] A. Bourke and B. Hui, "Weak evidence that HBOT is of benefit in the treatment of patients with herpes zoster," Diving and Hyperbaric Medicine, vol. 43, no. 3, p. 174, 2013.
[72] L. Bendtsen, J. M. Zakrzewska, J. Abbott et al., "European academy of neurology guideline on trigeminal neuralgia," European Journal of Neurology, vol. 26, no. 6, pp. 831-849, 2019.

[73] Headache Classification Committee of the International Headache Society (IHS), "The international classification of headache disorders, 3rd edition," Cephalalgia, vol. 33, no. 9, pp. 629-808, 2013.

[74] M. H. Bennett, C. French, A. Schnabel, J. Wasiak, P. Kranke, and S. Weibel, "Normobaric and hyperbaric oxygen therapy for the treatment and prevention of migraine and cluster headache," The Cochrane Database of Systematic Reviews, vol. 28, no. 12, 2015.

[75] D. S. Luo, T. Zhang, C. X. Zuo et al., "An animal model for trigeminal neuralgia by compression of the trigeminal nerve root," Pain Physician, vol. 15, no. 2, pp. 187-196, 2012.

[76] D. C. Yeomans and M. Klukinov, "A rodent model of trigeminal neuralgia," Methods in Molecular Biology, vol. 851, pp. 121-131, 2012. 